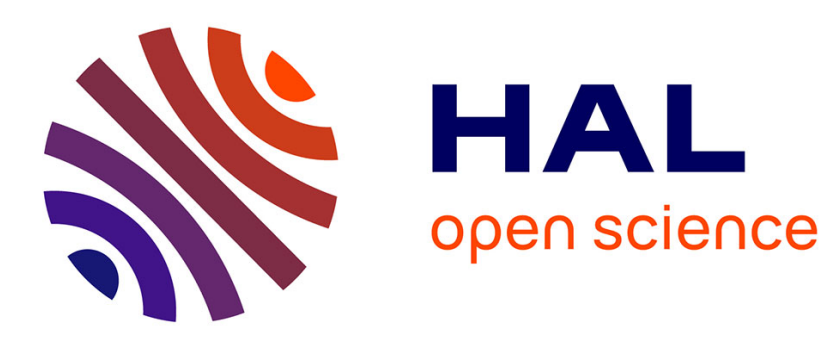

\title{
Assessing the World Bank's influence on the good governance paradigm
}

Gaoussou Diarra, Patrick Plane

\section{To cite this version:}

Gaoussou Diarra, Patrick Plane. Assessing the World Bank's influence on the good governance paradigm. 2011. halshs-00555814v3

\section{HAL Id: halshs-00555814 \\ https://shs.hal.science/halshs-00555814v3}

Preprint submitted on 5 Sep 2011

HAL is a multi-disciplinary open access archive for the deposit and dissemination of scientific research documents, whether they are published or not. The documents may come from teaching and research institutions in France or abroad, or from public or private research centers.
L'archive ouverte pluridisciplinaire HAL, est destinée au dépôt et à la diffusion de documents scientifiques de niveau recherche, publiés ou non, émanant des établissements d'enseignement et de recherche français ou étrangers, des laboratoires publics ou privés. 


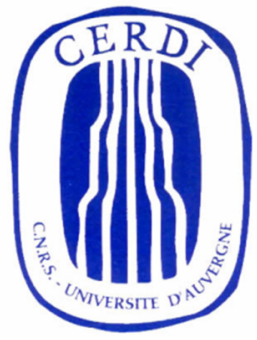

CENTRE D'ETUDES

ET DE RECHERCHES

SUR LE DEVELOPPEMENT

INTERNATIONAL

Document de travail de la série

\title{
Etudes et Documents
}

E 2011.27

\section{Assessing the World Bank's influence}

on the good governance paradigm

\author{
Gaoussou Diarra \\ and \\ Patrick Plane
}

août 2011

CERDI

65 BD. F. MITTERRAND

63000 CLERMONT FERRAND - FRANCE

TEL. 0473177400

FAX 0473177428

www.cerdi.org 


\section{Les auteurs}

\section{Gaoussou Diarra}

PhD student, Clermont Université, Université d'Auvergne, CNRS, UMR 6587, Centre d'Etudes et de Recherches sur le Développement International (CERDI), F-63009 Clermont-Ferrand, France

Email : dgaoussou2003@yahoo.fr

\section{Patrick Plane}

Researcher, Clermont Université, Université d'Auvergne, CNRS, UMR 6587, Centre d'Etudes et de Recherches sur le Développement International (CERDI), F-63009 Clermont-Ferrand, France

Email :P.Plane@u-clermont1.fr

Corresponding author: dgaoussou2003@yahoo.fr

La série des Etudes et Documents du CERDI est consultable sur le site :

http://www.cerdi.org/ed

Directeur de la publication : Patrick Plane

Directeur de la rédaction : Catherine Araujo Bonjean

Responsable d'édition : Annie Cohade

ISSN : 2114-7957

\section{Avertissement :}

Les commentaires et analyses développés n'engagent que leurs auteurs qui restent seuls responsables des erreurs et insuffisances. 
Abstract

What does governance mean for the World Bank and to what extent does the organization succeed in diffusing the paradigm worldwide? The World Bank primarily focused on economic aspects of governance in the 1980s, and progressively moved to its political dimensions towards the end of 1990s. The paper discusses the reasons for this global shift and its consistency with regard to the values of the liberal society. Bibliometric methods are used to evaluate the role of the Bank as a producer of knowledge on this specific issue. The potential influence of the World Bank's main governance indicators: Country Policy and Institutional Assessment (CPIA), Worldwide Governance Indicators (WGI) and Doing Business, is depicted through what donors claim when allocating aid, and beyond rhetoric, through what correlations suggest. For each of the main international donors, cross-sectional econometric regressions are run on large samples of developing countries (2005-2008). Depending on the donor we look at, empirical results do not reject strong covariations between new aid commitments and the CPIA, and to a lesser extent with the WGI.

Key Words: The World Bank, governance, liberal society, soft power, aid commitments

\section{Acknowledgements}

The authors thank P. Guillaumont and K. Gerd-Giesen from the University of Auvergne, C. N. Murphy, Wellesly College; S. Ndegwa and C. Muller from the World Bank as well as the participants to the RAD Doctoral Workshop on International Organizations at the World Bank ABCDE conference (Stockholm, May-June 2010) and the DIIS conference on Governing through standards (Copenhagen, February, 2010) for helpful comments. Usual disclaimer applies. 


\section{INTRODUCTION}

Many social sciences refer to good governance practices. Political scientists define the subject through the analysis of the relations between rulers and ruled, the functioning of political regimes, and the way institutions work. Economists focus on the quality of resource allocation, and the best way to provide the largest utility within the community. In the liberal contract, political and economic values combine in a normative situation, in which the maximum individual freedom goes along with the market as the main institution for resource allocation within the economy. An extensive literature already exists on the problem about the concept or the practical problems arising with the measurement of governance indicators ${ }^{1}$. Our intention in this paper is to shed some light on how the World Bank (WB or the Bank) has shaped this concept over a twenty year period since the end of the 1970s when the issue rose to the forefront of the development agenda. At that time, the Bank referred to this phenomenon to explain major economic failures in the public management of the poorest countries $^{2}$ (World Bank, 1989). The organization progressively moved to the political dimension, and beyond the welfare State economy that inspired the first decades of its functioning ${ }^{3}$. Both the fall of the Berlin wall, and the end of the ideological competition contributed to shape liberal governance ${ }^{4}$.

The next section of the paper outlines the genesis of ideas on governance within the Bank. The organization proved sensitive to the external thinking of academics, and contributed itself to defining the paradigm of good governance over nearly three decades. Section 3 focuses on the relationship between the 'Knowledge Bank' and the governance issue. We quantify the "soft power" of the Bank by the relative importance of this theme in its intellectual production. Section 4 focuses on the WB's aid allocation system which combines both soft and hard power principles. ${ }^{5}$ The WB's main governance indicators: the Country Policy and

\footnotetext{
${ }^{1}$ See Arndt and Oman, 2006; Kaufmann and Kraay, 2008; Williams and Siddique, 2008; Langbein and Knack, 2010; Razafindrakoto and Roubaud, 2010.

${ }^{2}$ See: Stein, 2008; Shihata, 1995; Williams and Young, 1994; Stone and Wright, 2007; Tshuma, 1999, Brautigam, 1991.

${ }^{3}$ See Joseph, 2000; Miller-Adams, 1999; Owusu, 2003; Pender, 2001; Shihata, 1995 ; Harrison, 2005; Devesh et al, 1997.

${ }^{4}$ Fukuyama (1992) was among the most prominent authors to predict the global triumph of political and economic liberalism adopting the Hegelian perspective of a progressive humanity evolving to a universal ideology.

${ }^{5}$ According to Nye (1990), leadership is not just a question of issuing commands through inducements or threats; soft power also matters. "Soft" power is characterized by the ability to shape the preferences of others through persuasion, or attraction that leads to acquiescence. Conditionality principles proceed from a hard power while the diffusion of the Bank's paradigm in the member state
} 
Institutional Assessment (CPIA), the Worldwide Governance Indicators (WGI), and the Doing Business indicators (DB) are briefly analysed, as well as the importance that the donor community assigns to each of them in allocating funds. Beyond what donors claim, we also explore how actual financial commitments correlate with these indicators, controlling for some structural determinants of aid allocation. For each donor, cross-sectional regressions run on developing countries over a four year average period (2005-08) do not reject the presence of linear correlations. For some donors the CPIA seems to be the most important, especially for regional multilateral banks; while bilateral donors such as France and to a lesser extent the United Kingdom demonstrate a "path dependency" with an allocation rule determined by their own past colonial history. The CPIA proves influential, while both the WGI and the information conveyed by the Doing Business matter less. Section 5 provides conclusions.

\section{THE BANK AND THE GOVERNANCE PARADIGM OVER TIME}

The Landell-Mills coordinated 1989 report: Sub-Saharan Africa, from Crisis to sustainable Growth (World Bank, 1989) has generally been considered as the first official WB publication which refers explicitly to the "governance" issue (Williams and Young, 1994; Shihata, 1995; Stein, 2008). This does not mean that the theme was ignored before. At the beginning of the 1980s, the so-called Berg report explained the low economic growth rates in Sub-Saharan Africa, and called attention to the responsibility of non-Weberian African public bureaucracies (World Bank, 1981). Governance was not explicitly designated as a crucial problem, but the poor management underlying public sector weaknesses was denounced as a major hindrance to the development process ${ }^{6}$.

Redefining state interventions and market mechanisms was the challenge of the neo-liberal wave, ${ }^{7}$ getting the prices right became the credo of structural adjustment programs. Within the Bank the liberal option took a decisive turn in 1981 with the appointments of Claussen and Krueger, respectively as the President and the Chief Economist of the organization, succeeding the charismatic tandem of MacNamara and Chenery. Under the influence of the

community relates to a soft power. On this point, see: Mosley et al., 1995; Van Waeyenberge, 2009; Storey, 2000; Plehwe, 2007.

${ }^{6}$ From the beginning of the 1950's to the end of the 1970's, the welfare state principles prevailed and the Bank supported public interventionism in developing countries to bypass inefficient market mechanisms. Governments were encouraged to take the lead in the development process.

${ }^{7}$ See Cling and Roubaud, 2008; Mawdsley and Rigg, 2003; Stein, 2008; Stiglitz, 1999; Kapur et al, 1997. 
Reagan administration, the Bank was exhorted to use its financial leverage, to support the free market perspective (Williams and Young, 1994), and to promote the worldwide neo-liberal order, complying with the rules of the "Washington consensus". Progressively, the conception of "good governance" becomes to be associated with the "free market" economy, the Victorian virtues of free markets and sound money, as the key of economic development. All the chief economists from A. Krueger (1982-86) to M. Bruno (1993-96) belong to this school of thought with its institutional, political and social extensions defining the so-called "augmented Washington consensus"

In 1992, Governance and development brings further information on what governance means for the Bank, highlighting both the course of history and the institutional constraints inhibiting the evolution of the concept within the organization ${ }^{9}$. On the one hand, the introduction of the pamphlet refers to a general definition of governance which can be seen as the exercise of authority, control, management and power of government. On the other hand, a pragmatic definition drives the Bank to interpret governance as the manner in which power is exercised in the management of a country's economic and social resources for development. The concern is that good governance is to be seen as synonymous with sound development, thus extending beyond public sector management to the principles of accountability, and the legal framework. While the Bank seems to reject the political dimension, the booklet suggests that there is no taboo anymore on the subject (World Bank, 1992, 1994). As the Berlin Wall has fallen, but the Soviet empire has not collapsed, the organization remains cautious on ideology, and what can be interpreted as an assessment of political regimes. A lot of World

\footnotetext{
${ }^{8}$ The concept of Washington Consensus was developed for the first time in Williamson (1990), Latin American Adjustment: How Much Has It Happened? Washington, D.C.: Institute for International Economics. See Onis and Senses (2005) and Rodrik (2006) for more details. The original Washington Consensus was based on: 1. Fiscal discipline; 2. Reorientation of public expenditures; 3 . Tax reform; 4. Financial liberalization; 5. Unified and competitive exchange rates; 6 . Trade liberalization; 7. Openness to DFI; 8. Privatization; 9. Deregulation; 10. Secure Property Rights. The "Augmented" Washington Consensus enlarges the previous items with: 11. Corporate governance; 12. Anticorruption; 13. Flexible labour markets;, 14. WTO agreements; 15. Financial codes and standards; 16. "Prudent" capital-account opening; 17. Non-intermediate exchange rate regimes; 18. Independent central banks/inflation targeting; 19 . Social safety nets; 20 . Targeted poverty reduction.

${ }_{9}^{9}$ The 1992 pamphlet refers to a definition of the governance given by the Webster's New Universal Unabridged Dictionary (London: Dorset \& Baber, 1979). Governance has three distinct aspects: (a) the form of political regime (parliamentary or presidential, military or civilian, and authoritarian or democratic); (b) the processes by which authority is exercised in the management of a country's economic and social resources; and (c) the capacity of governments to design, formulate, and implement policies, and, in general, to discharge government functions. The first aspect clearly falls outside the Bank's mandate. The Bank's focus is, therefore, on the second and third aspects. (See: World Bank, 1992; 1994; 2001a; 2001b).
} 
Bank member countries do not really comply with the conditions of western democracy. Free political competition only exists in few developing countries, and then the realpolitik principle has to apply. In addition, formal democracy is not enough. Pluralism needs the promotion of the rule of law, as well as the participatory process of civil society performing "watchdog" functions. At that time the Bank avoids any dangerous correlation of good governance with the main features of the western neo-liberal political system. The first infringement to this "neutrality" came with J. Wolfensohn, when in 1996 the agenda for anticorruption was launched. At the joint World Bank-IMF annual meeting, the head of the Bank talks about the need to fight the "cancer of corruption". One year later the same words come up in "Helping Countries Combat Corruption", and in the World Development Report which addresses the problem of the State in a changing world. In the foreword of this report, Wolfensohn made the point that an effective State works for the market, not as a director. In addition, he stresses the role of the civil society, which was already perceived by Tocqueville as "the ultimate guarantee that the state will be unable to arrogate to itself any more power than an active citizenry is willing to grant" (World Bank, 1997).

The "good" governance concept, initially limited to public management reforms and later to the building of the free market economy, then becomes a more complex phenomenon with the introduction of political values. Democracy is the reference with the presence of "checks and balances", including those associated with the participatory process of the civil society. We will return later to the indicators operationalizing these views, but in 1999 this political dimension was taken into account to revisit the definition of the Country Policy and Institutional Assessment (CPIA), which was the first World Bank governance indicator created at the end of 1970s. The main outcome of this revision was to incorporate some items relating to property rights and rule-based governance, as well as to transparency and corruption in the public sector. For a long time, the CPIA had been a pure intra-organizational instrument for the Bank's internal country evaluations. Together, the transparency rules and the accountability principles, that are required from member countries, as well as the will to measure the political distance to democracy or the stimulation of the social participatory process, help the progressive diffusion of information externally. In addition to the CPIA revision and its diffusion within the world community, in 1999 the Bank also launched the calculation of the Worldwide Governance Indicators whose construction and international cover have deeply evolved over the last ten years ${ }^{10}$.

\footnotetext{
${ }^{10}$ See Kaufmann et al, 2008.
} 
In parallel to this indicator, to which we return later, in 1998 the Comprehensive Development Framework (CDF) was created, encompassing a set of principles to guide poverty reduction, including a holistic long-term vision of development. This initiative was taken while the weaknesses of the "Washington Consensus" were being criticized; standard policy reforms having failed to produce expected outcomes in terms of economic growth and poverty reduction. A second generation of reforms was needed, the so-called "augmented Washington Consensus", which is heavily institutional in nature (see, Rodrik, 2006). Economic programmes have to extend to governance, anti-corruption, legal and administrative reforms, labour market flexibility and social safety nets. Within the Bank, Stiglitz, who is appointed as the new Chief Economist in February 1997, supports this refashioning, encouraging a movement beyond liberalization and privatization, and reminding us that the market does not always provide the most efficient outcome. The CDF emphasizes the need to create the institutional underpinnings of market economies, and to tackle poverty as a primary ambition.

Using the CDF principles, a country defines its vision of the development process in close collaboration with all domestic and external stakeholders (civil society, private sector, donors). The CDF inspired the Poverty Reduction Strategies (PRS) and helped to shape the United Nations declaration (2000) concerning the Millennium Development Goals (MDGs), as well as the Monterrey consensus, which committed developing countries to set up "good" governance. Strictly speaking, poverty reduction is not a new objective, being a major element of the original charter of the Bank. But what is new is that beyond the "trickle down" theory that urged governments to concentrate on maximizing GDP growth rate, the poverty reduction strategy now conflicts with post Second World War redistributions based on reduction of income inequalities. The economy is seen as efficient when achieving the maximum output of preferred goods and services from available resources. But this dimension, reflecting the economic governance, is not enough. Income distribution associated with output is also important. It must be seen to be "just" or "fair"; the problem being to specify what this distribution should be. This is not an issue where economists are very influential. The definition of distributional efficiency belongs more to the realm of moral and political philosophy. However, at the turn of the century, the concept of a liberal distributional efficiency prevails in the world community and deeply influences the Bank. The 2006 World Development Report illustrates this new philosophy and finalizes what must be considered as "good governance" from the liberal standpoint. 
Public action should focus on the distribution of assets, economic opportunities, and political voice, rather than directly on inequality of incomes. Greater equity implies more efficient economic functioning, reduced conflict, greater trust, and better institutions, with dynamic benefits for investment and growth. When these rules apply in a market economy, income differences then provide incentives to invest in education and physical capital, to work, and to take risks. Income inequalities are consubstantial to the efficiency of the market economy, and prove inacceptable only if there are predetermined circumstances out of individual control. "Equal opportunity" may be considered to be the basic principle underlying the promotion of equity, and this means the possibility for individuals to benefit from the same abilities, to pursue a life of their choosing, and to be spared from extreme deprivation in outcomes. With the strategic orientations of its 2006 World Development report, the Bank has completed its liberal interpretation of governance beyond the Western spirit of welfare state economics. Its philosophy integrates Sen's line of thought, but is also impregnated with Rawls's liberal political philosophy based on fairness in the distribution of "natural" and "social primary goods". It also takes into account Dworkin's vision of the unity of political and economic liberalism through its conception of equality (e.g. luck, egalitarianism). Accordingly, the Bank has drawn the lessons of the 1980s when it was urged to promote adjustment processes with a "human face" and criticized for its excessive concern for relative prices.

After maturing for several decades, the World Bank's "good governance" finally looks like something quite close to what the philosophers of the enlightenment had in mind: a paradigm embracing political, economic and social aspects that make the equilibrium of an efficient liberal society. However, the question of whether the paradigm must be considered as a universal one or not, is still being debated. Fukuyama (1992) defended this perspective in The End of History and the Last Man predicting that human rights, liberal democracy and the capitalist free market economy together were to become the unique ideological term of reference. Conflicting with this perspective, Huntington (1993) announced cultural divisions and the evolution to a Clash of Civilizations. Many economists also qualify Fukuyama's views, at least as regards the values and the channels leading to development. Stiglitz as well as Rodrik (2006) reject the hypothesis of an exhaustion of all institutional variations that could "underpin healthy and vibrant economies". In a world combining global governance and multipolar power, the "good governance" issue will remain challenging. As a pragmatic organization, the Bank remains open to ideas outside the conventional paradigm. The role of 
the State and public organizations in the design of development strategy illustrates this behavior. Indeed, this role is much more balanced than it was thirty years ago.

\section{THE KNOWLEDGE BANK AND THE GOVERNANCE ISSUE}

The development of the organization as a "Knowledge Bank" was one of the major objectives of Wolfensohn's Presidency. This new vision was the combination of the President's corporate pragmatism and Stiglitz's own academic influence on the emergence of information economics. At the end of the 1990's the organization was more than ever focused on a triptych consisting in creating and sharing knowledge for applying "best practices" in member states (Squire, 1999; Mehta, 2001; Krueger, 1998; Das, 2009; McNeill, 2006; Plehwe, 2007 ; Stiglitz, 1999). If knowledge production and its diffusion are mainly the concern of the Research Department (DEC), especially through the activity of the Development Research Group and the World Development Report Unit, additional structures also contribute on the governance issue ${ }^{11}$. The Poverty Reduction and Economic Management network (PREM) is engaged in the production of the CPIA. This structure operates in close cooperation with the World Bank Institute (WBI), which is in charge of the WGI and the country-governance profiles, the so-called diagnostic surveys of Governance and Anti-Corruption (GAC). Last but not least, the recent Deaton report on Bank research evaluation has brought attention to the Private Sector Development Group (Banerjee et al, 2006). Based at the International Finance Corporation (IFC), this group is a significant contributor to the governance theme through both the Doing Business and the Investment Climate Assessment projects.

One way to assess the Bank's influence is to perform a bibliometric analysis. This exercise has been carried out, using the Web of Science bibliographic database from the ISI Web of Knowledge website (Institute for Scientific Information -ISI) published by Thomson Reuters. We evaluate the role governance played within the organization but also the Bank's share in the worldwide production of knowledge on this specific issue. Governance-based publications

\footnotetext{
${ }^{11}$ For Gilbert et al (1999), the DEC is the most important centre for development economics worldwide, with some influential implications on academia that are noted by S. Fisher (1995). While recognizing this impact and the ability to promote development schemes, some authors such as Gavin and Rodrik (1995) or Stern and Ferreira (1997) qualify these views, asserting that no major economic idea had ever resulted from in-house production.
} 
in the most influential journals are considered, as well as associated citations in the academic literature. This combined information provides an insight on the relative importance of the Bank on the governance issue.

To undertake the census of publications we retain the presence of "governance" as a term either in the title, the abstract or the list of keywords. A paper is ascribed to the Bank if the name of the organization appears as one affiliation of its authors. Materials collected are classified according to the subject area, the document type and the year of publication. Publications are defined by 4 items: article, review, proceedings, book review. Three large scientific fields have been considered, from 200 listed by the Web of Science database: Economics, planning and development; Business and finance; Political science and international relations. These fields fit the main intervention areas of the Bank, where governance proves a relevant topic for characterizing the economic and political rules of societies. Additional domains did not modify the conclusions we draw. They partially overlap with the three chosen ones, which represent one third of all publications from all scientific disciplines, including company management or environmental studies, ${ }^{12}$ where governance is a topic. The investigation covers the period $1988-2008^{13}$. The starting year corresponds with the emergence of the concept in the economics literature.

Figure 1 describes both the annual evolution of the worldwide scientific production on governance (left ordinate axis and light color stair form representation), and the specific contribution of the Bank to this production (right ordinate axis). The worldwide publications on this issue have increased in a quasi-permanent way since the early nineties. Accelerating at the end of the empirical period when 800 publications a year are recorded against ten at the beginning of the 1990s. Within this production, the Bank's share has varied from less than $1 \%$ to more than $3 \%$. This share decreased as the world scientific community displayed a greater interest for the topic, while the pioneering role of the Bank reduced. The peak of the share is achieved in the period 1999-2000, when the organization showed renewed interest for the analysis of the governance issue, especially through the CDF program and the launch of the project on the WGIs. After this period, the Bank's relative contribution declined to represent only $1.5 \%$ in 2008 .

\footnotetext{
${ }^{12}$ The problem with the subject classification is that some publications are often put in multiple areas simultaneously. This fact could lead to an overestimation of the weight of individual subject areas. So we solved this issue by pooling these three subject areas for our analysis sample.

${ }^{13}$ The bibliometric analysis ends in April 2009
} 


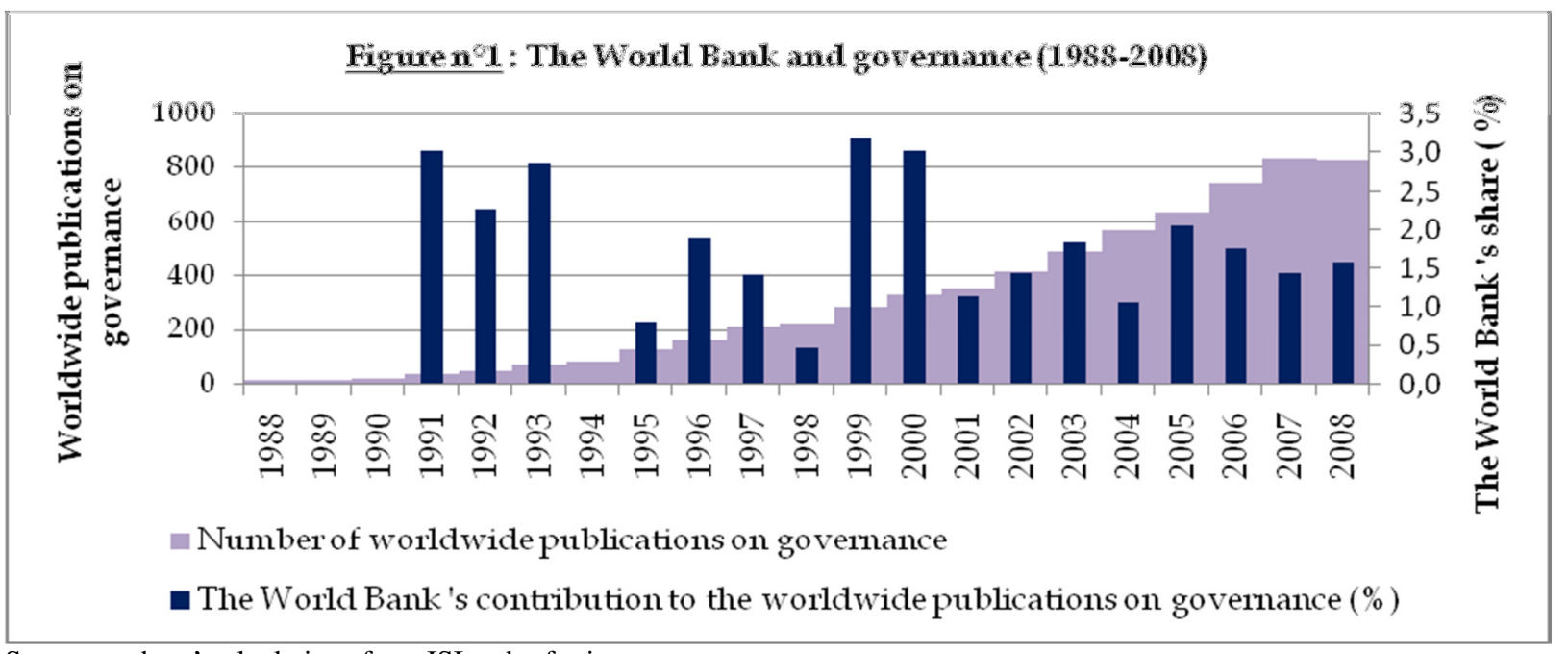

Source: authors' calculations from ISI web of sciences.

In Figure 2, we assess what the governance issue represents within the total academic publication of the Bank. As in Figure 1, a double graduation is used on two different axes. On the left hand side, the number of total publications is considered, while on the right, we refer to the intra-organizational share of the governance theme. The scientific production of the Bank varies from 150 to 200 publications a year with a peak in 2001. Governance publications show an increasing trend, passing from a share of 1\% or less from 1988 to 1992 to about $8 \%$ over the period $2005-2008$.

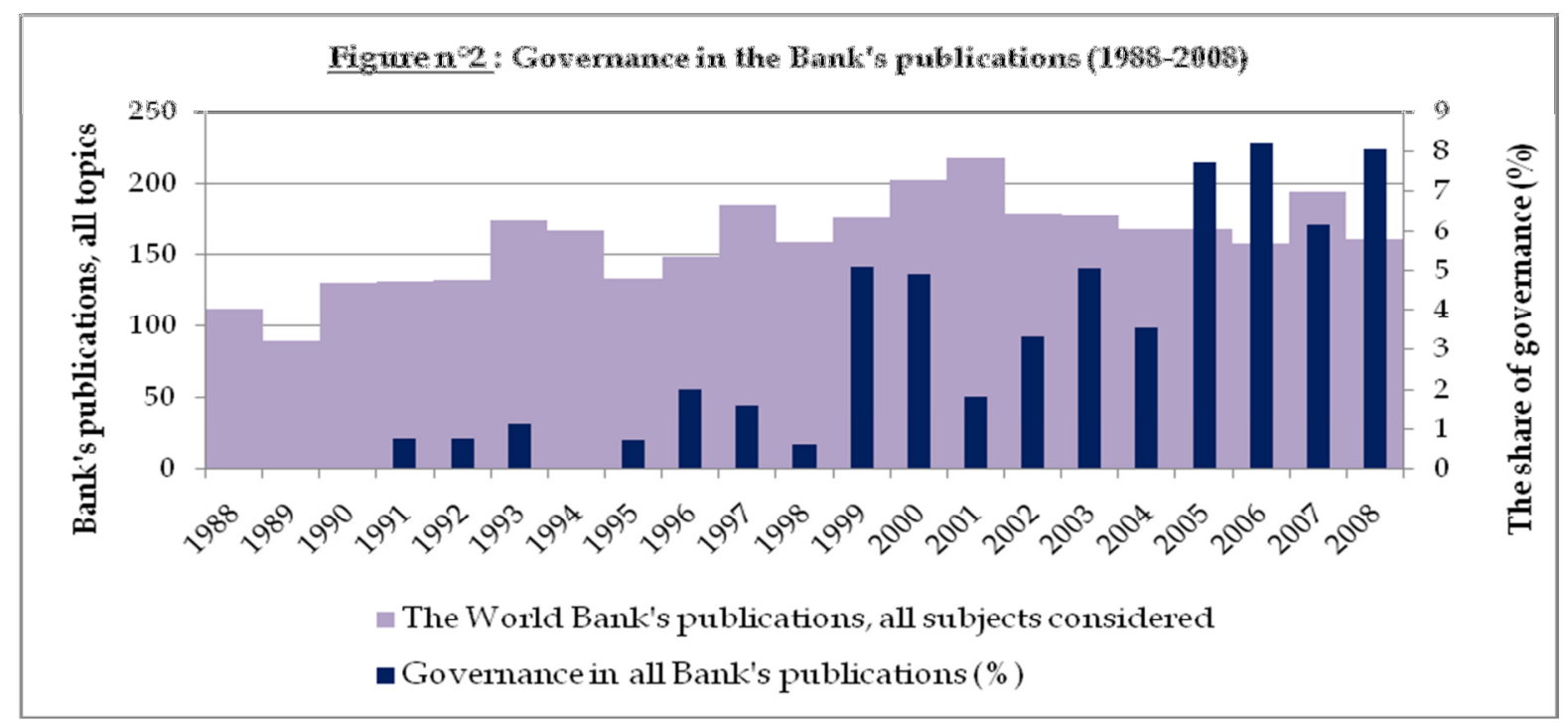

Source: authors' construction 
Table 1. The World Bank and cumulative publications on governance (1988-2008)

\begin{tabular}{|c|c|c|c|c|c|}
\hline \multirow[t]{2}{*}{ Subject areas } & \multirow[t]{2}{*}{$\begin{array}{c}\text { Nature of } \\
\text { Publications }\end{array}$} & \multicolumn{2}{|c|}{$\begin{array}{c}\text { Total WB publications } \\
\text { and governance share } \\
\text { in parentheses }(\%)\end{array}$} & \multicolumn{2}{|c|}{$\begin{array}{c}\text { Worldwide publications on } \\
\text { governance and } \\
\text { the WB's share } \\
\text { in parentheses }(\%)\end{array}$} \\
\hline & & Number & Citations & Number & Citations \\
\hline \multirow{3}{*}{$\begin{array}{l}\text { Economics, } \\
\text { planning and } \\
\text { development }\end{array}$} & $\begin{array}{c}\text { Articles and } \\
\text { reviews }\end{array}$ & $\begin{array}{l}2792 \\
(2.4)\end{array}$ & $\begin{array}{c}38562 \\
(1.9)\end{array}$ & $\begin{array}{l}2432 \\
(2.8)\end{array}$ & $\begin{array}{c}21452 \\
(3.4)\end{array}$ \\
\hline & $\begin{array}{c}\text { Proceedings } \\
\text { paper }\end{array}$ & $\begin{array}{l}501 \\
(4.4)\end{array}$ & $\begin{array}{l}3465 \\
(3.1)\end{array}$ & $\begin{array}{c}725 \\
(3.04)\end{array}$ & $\begin{array}{l}4115 \\
(2.6)\end{array}$ \\
\hline & Total & $\begin{array}{l}3912 \\
(2.4)\end{array}$ & $\begin{array}{c}42824 \\
(2)\end{array}$ & $\begin{array}{l}3723 \\
(2.5)\end{array}$ & $\begin{array}{c}25913 \\
(3.2)\end{array}$ \\
\hline \multirow{3}{*}{$\begin{array}{c}\text { Business and } \\
\text { finance }\end{array}$} & $\begin{array}{c}\text { Articles and } \\
\text { reviews }\end{array}$ & $\begin{array}{l}550 \\
(2.5)\end{array}$ & $\begin{array}{l}7982 \\
(4.6)\end{array}$ & $\begin{array}{l}706 \\
(2)\end{array}$ & $\begin{array}{l}10815 \\
(3.4)\end{array}$ \\
\hline & $\begin{array}{c}\text { Proceedings } \\
\text { paper }\end{array}$ & $\begin{array}{l}132 \\
(6.8)\end{array}$ & $\begin{array}{l}1348 \\
(1.5)\end{array}$ & $\begin{array}{l}238 \\
(3.8)\end{array}$ & $\begin{array}{l}2715 \\
(0.7)\end{array}$ \\
\hline & Total & $\begin{array}{l}766 \\
(3.2)\end{array}$ & $\begin{array}{l}9397 \\
(4.1)\end{array}$ & $\begin{array}{l}995 \\
(2.5)\end{array}$ & $\begin{array}{c}13606 \\
(2.8)\end{array}$ \\
\hline \multirow{3}{*}{$\begin{array}{c}\text { Political Sciences } \\
\text { and International } \\
\text { Relations }\end{array}$} & $\begin{array}{c}\text { Articles and } \\
\text { reviews }\end{array}$ & $\begin{array}{l}294 \\
(1.4)\end{array}$ & $\begin{array}{l}1763 \\
(0.8)\end{array}$ & $\begin{array}{l}1690 \\
(0.2)\end{array}$ & $\begin{array}{l}8580 \\
(0.2)\end{array}$ \\
\hline & $\begin{array}{c}\text { Proceedings } \\
\text { paper }\end{array}$ & $\begin{array}{c}39 \\
(2.5)\end{array}$ & $\begin{array}{l}207 \\
(0.5)\end{array}$ & $\begin{array}{l}323 \\
(0.3)\end{array}$ & $\begin{array}{l}1454 \\
(0.1)\end{array}$ \\
\hline & Total & $\begin{array}{l}439 \\
(1.6)\end{array}$ & $\begin{array}{l}2042 \\
(0.8)\end{array}$ & $\begin{array}{l}2821 \\
(0.2)\end{array}$ & $\begin{array}{c}10199 \\
(0.2)\end{array}$ \\
\hline
\end{tabular}

Sources: authors' compilations from ISI web of science

Table 1 displays cumulative statistics dealing with governance over two decades (1988-2008) and three scientific domains. Influences are measured through the intra-organizational academic production (columns 3 and 4) and the worldwide publications (columns 5 and 6). Both the number of papers and enhanced associated citations are considered in absolute and relative terms, the second item in parentheses being interpreted as an impact factor.

For the World Bank, Economics, planning and development is by far the most important field of publication, totaling nearly 4,000 articles or papers over the period 1988-2008, four times more than the cumulative production of the other two reviewed fields. (On average, each of these publications has been cited more than 10 times. These scores represent $2.5 \%$ of the total publications of the Bank and $3.2 \%$ of the citations. This is less than the numbers 
obtained for Business and finance: $3.3 \%$ and $4.1 \%$, respectively, although percentages are close when market shares in worldwide publications and citations about governance are considered. Of the three scientific fields, only Political science and international relations proves to be a marginal area for the Bank. Several reasons can be put forward to explain this fact, including the belated interest for political issues due to the apolitical nature of the organization, in accordance with its founding Articles of Agreement. Focusing on the two first subject areas, the international market share of the Bank tends to be higher when the citations are considered, reflecting either the quality of the publications or the diffusion of the journals in which the research is published.

The methodology deployed for this empirical analysis has some obvious limits that have to be taken into account in interpreting the results. As already mentioned, the concept of governance is shared by multiple scientific disciplines making its delimitation difficult. In addition, some restrictive rules condition this exercise. A paper is considered to deal with "governance" when the term is explicitly used in the title, abstract or keywords. This convention results in an undervaluation of the publications of the 1980s, when the governance concept was conveyed by other expressions ${ }^{14}$. To avoid such a bias, the automatic research procedure has been complemented by manual mechanical counting in ten of the most important academic journals in economics, including those which are the main sources for the Bank's authors publications. In doing so, attention has been paid to the theme itself, and not to a lexical list. These ten journals are : The American Economic Review, the Quarterly Journal of Economics, the Journal of Development Economics, World Development, Economic Development and Cultural Change, The World Bank Economic Review, The Journal of African Economies, The Journal of Development Studies, The Journal of Comparative Economics and Economics of Transition.

Figure 3 has been elaborated according to the same principles used for Figure 2. The number of the Bank's articles in the ten aforementioned journals and the relative contribution of the governance issue are given on the left and right axes, respectively. The dark curve reflects what these economic journals have represented for the total publications of the Bank. About 40 papers have been published annually in the ten journals over the period 1988-1994,

\footnotetext{
${ }^{14}$ For instance, the well-known 1989's report of the World Bank, Sub-Saharan Africa: from crisis to sustainable growth (World Bank, 1989) was its first report indexing explicitly the issue of governance as the key factor of weak economic performance in African countries while the French version of the report used the term "government" instead of "governance".
} 
against 50 per year from 1997 to 2005, and about 30 for the most recent years. Within this production, the governance issue rose steadily to a peak of 25\% in 2003 and 2004. Then the share fell back to its 1995 level (10\%). While the governance issue declined after the mid 2000s, the contribution of what the selected journals have represented for the Bank also witnesses long term erosion. As the ten journals we refer to are among the most influential in the world, the evolution of the dark curve may suggest a significant loss of qualitative impact in the production of knowledge by the Bank. The contribution of the ten journals to the total publication of articles by the Bank falls from 35\% in 1988 to about $15 \%$ in 2008 .

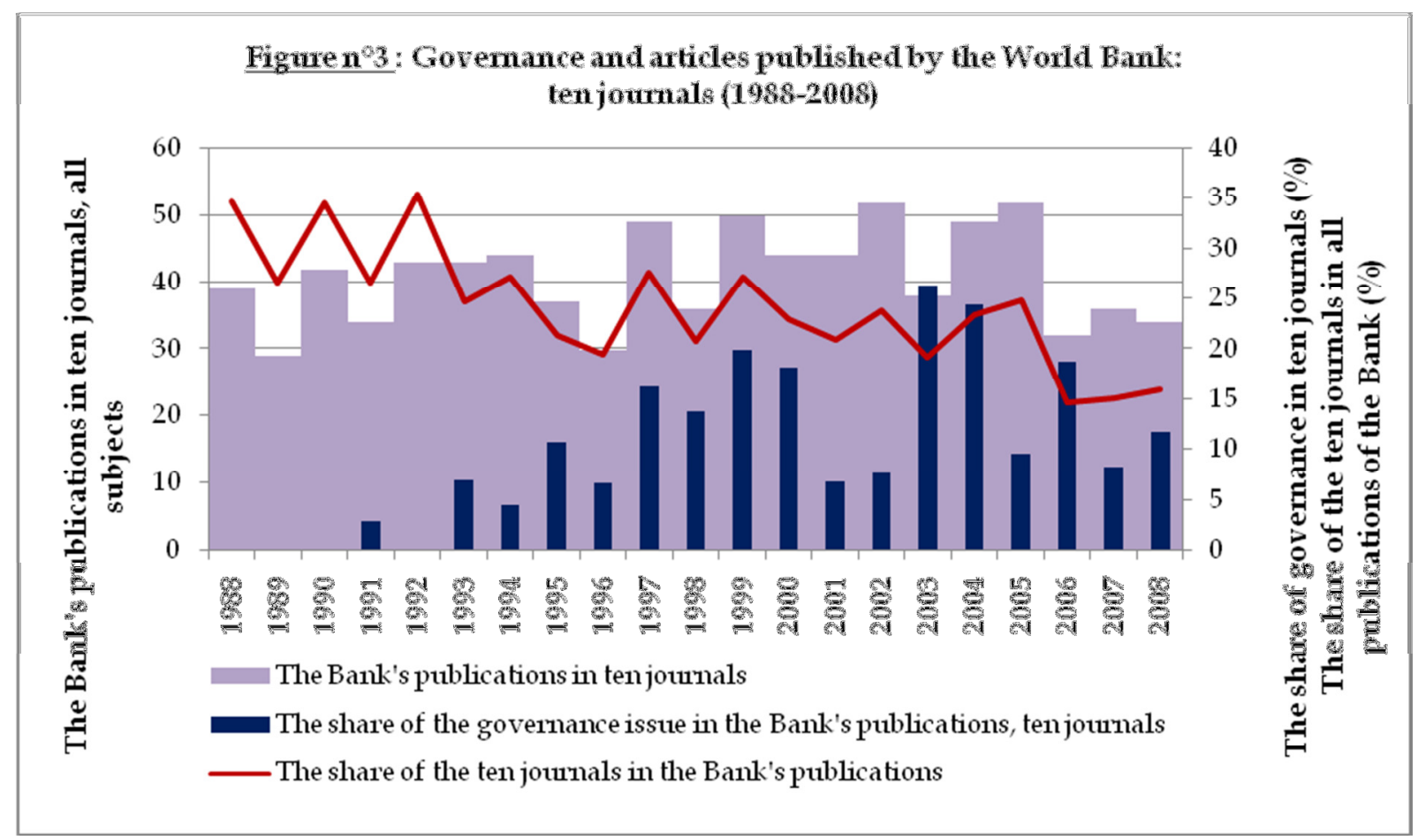

Source: authors' construction

To summarize this section, academic publications and citations of papers play a significant role in the production of the "knowledge bank", contributing to strengthen the soft power of the organization (to adopt Nye's, 1990 expression). This soft power dimension is also present when the Bank sets up the dialogue with developing countries and the donor community in accordance with the CDF principles. Governments define their development strategy by promoting dialogue among stakeholders. The leadership of the Bank lies in its ability to communicate and persuade partners, to shape their preferences, and to lead them to acquiescence. Soft power in public aid allocation means the ability to convince the recipient that there is no doubt about what "good governance" principles are. Contrasting with this kind of influence is the Hard power which operates as an inducement, and sometimes as a threat; 
similar to the IMF conditionality on loans and its catalytic role. The leadership of the Bank is therefore made up of a balance between soft and hard power, a subtle combination which leads to what some may refer to as smart power. The next section explores these powers by focusing on aid allocation policies.

\section{THE BANK GOVERNANCE INDICATORS AND AID ALLOCATION POLICIES}

We briefly describe the WB's governance indicators, and then investigate how these indicators correlate with aid commitments of the most important international donors, including the World Bank itself. ${ }^{15}$

\section{The governance indicators: CPIA, WGI and Doing Business}

The World Bank produces three main indicators dealing with governance. The oldest one is the Country Policy and Institutional Assessment. Although the CPIA is not fully disclosed to external public, it is paradoxically recognized by some donors as the most influential of the WB's indicators. This is especially true for commitments in favor of IDA eligible countries, but also for some other donors (Van Waeyenberge, 2009). At the end of the 1990s the sociopolitical dimension of governance took an increasing importance in the World Bank's agenda. The Worldwide Governance Indicator (WGI) resulted from this concern. This socio-political dimension was completed, in 2003, by the Doing Business indicators that depict to what extent the domestic economic and institutional climate supports private sector development ${ }^{16}$.

\footnotetext{
${ }^{15}$ In Assessing aid, which proved to be an influential publication of the Bank, governance was conceived as a crucial element of aid effectiveness, contributing to drive resource allocations (World Bank, 1998; Burnside and Dollar, 2000, Santiso, 2001). This perception was strongly debated in the literature as good governance can be endogenous to structural vulnerabilities (Guillaumont and Chauvet, 2001; Van Waeyenberge, 2009). Soft power provides information on the quality of governance while hard power potentially applies when aid disbursement is interrupted because of poor governance-based performance. See also Duffield (2002) for critics on the social dimensions of development and the use of aid in a context of global liberal governance.

${ }^{16}$ This narrow list of the World Bank's indicators could be extended with others benefiting from a more limited international statistical coverage. This is the case for the indicator of the Database on Political Institutions both conceived and followed by the World Bank's research department since 2000. The DPI explicitly deals with the nature of political regimes worldwide.
} 
The Country Policy and Institutional Assessment

The CPIA, originally the Country Performance Rating (CPR) was established in 1977. It relies on an assessment process based on the Bank's staff opinions. Since 1998, two additional clusters have been added to the initial ones: the social inclusion dimension (cluster C) and the governance dimension (cluster D) ${ }^{17}$ (World Bank, 2010). The CPIA measures how the domestic policy and the institutional framework support sustainable growth and poverty reduction. Accordingly, this indicator reflects the role of the governance issue and conditions aid effectiveness. By adding a social and political dimension to the CPIA, the World Bank joined the weave of the "augmented" Washington Consensus (Van Waeyenberge, 2009).

The CPIA is a key element in the International Development Association (IDA)Performance-Based Allocation (PBA) system. This allocation takes into account several criteria including the size of the population, the Bank's portfolio performance and the level of economic development of member countries. With the "IDA 16" replenishment process, the governance component accounts for $68 \%$ in the weighting pattern of the $\mathrm{CPR}^{18}$.

The CPIA has some users outside the Bank, especially in regional multilateral banks (e.g. African Development Bank (AfDB), Asian Development Bank (ADB), Inter-American Development Bank (IADB)), which have adopted the same methodology, using sometimes the same denomination of items and marginally modifying either the definition, the components or the weighting pattern.

\footnotetext{
${ }^{17}$ The 4 clusters are: A. Economic Management (Macroeconomic Management, Fiscal Policy, Debt Policy); B. Structural Policies (Trade, Financial Sector, Business Regulatory Environment); C. Policies for Social Inclusion (Gender Equality, Equity of Public Resource Use, Building Human Resources, Social Protection and Labour, Policies and Institutions for Environmental Sustainability); D. Public Sector Management and Institutions (Property Rights and Rule-based Governance, Quality of Budgetary and Financial Management, Efficiency of Revenue Mobilization, Quality of Public Administration, Transparency, Accountability, and Corruption in the Public Sector). For each of the 16 criteria, countries are rated on a scale of 1 (low) to 6 (high)

${ }^{18}$ (i) Capped blend countries, whose allocations are capped at levels below what the PBA formula would allocate to them; (ii) post-conflict and reengaging countries, where IDA can provide special support for their recovery and development needs; (iii) arrears clearance operations; (iv) regional projects that play a key role in regional integration and/or regional public goods; and (v) exceptional allocations in the aftermath of natural disasters. These exceptions represent sometimes $1 / 3$ of the IDA total resources (World Bank, 2010).
} 
The Doing Business project database

The Doing Business (DB) project was initially inspired by some studies conducted by de Soto in the Lima suburbs in the 1980s, but also by the World Economic Forum (WEF) through the Global Competitiveness Report. Influences between the Bank and the Forum are now much more mutual with clear interactions between the two institutions. Indeed, some information from $\mathrm{DB}$ is incorporated into the benchmarking procedure of the WEF for the measurement of international competitiveness. Laporta, Lopez de Silanes, Shleifer and Vishny (LLSV) have extended the pioneering empirical work through the IFC/World Bank team of the $D B$ led by Djankov. The $D B$ Project aims at reducing the burden of business regulatory rules, notably transaction costs, in order to enhance economic competitiveness of countries. The first edition of the report, launched in 2003, covered 5 indicators in 133 countries: Starting a business, Employing workers, Getting credit, Enforcing contracts, Closing a business. This list, which was enlarged in 2006, now contains 10 indicators, the 5 additional ones being: Dealing with construction permits, Registering property, Protecting investors, Paying taxes, Trading across borders. In the 2009 Bank report, a survey on the business regulatory environment was implemented allowing the assessment of the ability to reform through difficult times (World Bank, 2009). The data collection is made through readings of laws and regulations where the criteria are time, motion and cost indicators measuring efficiency in achieving a regulatory goal $^{19}$. The $D B$ database seems to impact donors' aid allocation systems as demonstrated by the eligibility criteria to benefit the US Millennium Challenge Account (MCA).

\footnotetext{
${ }^{19}$ By soliciting legal practitioners or professionals who regularly undertake transactions, Doing Business Project differs from other business environment surveys. For instance, the Investment Climate Assessment (ICA), which is also a World Bank research program, refers to the feeling of private managers and then appears more sensitive to subjectivity than the Doing Business. Indeed, managers may reject the responsibility of the economic inefficiency to the external environment they have to assess.
} 


\section{The Worldwide Governance Indicators (WGI)}

The WGI, were launched in 1999 defining governance as the traditions and institutions by which authority is exercised in a country ${ }^{20}$. "Governance" is assessed for about 200 countries through six dimensions: Voice and Accountability, Political Stability and Absence of Violence, Government Effectiveness, Regulatory Quality, Rule of Law, and Control of Corruption (Kaufmann et al, 2008). The WGI have probably become the most important database dealing with the political dimension of governance. The WGI are not considered as accomplished "state of art", and the way they are constructed is periodically adjusted according to both internal and external thinking. This strategy illustrates the smart power of the Bank, where the willingness to take the lead on the definition of the indicators combines with openness to the participation of other donors in helping to shape a common knowledge on what good governance is.

The three governance indicators are all influential, but nevertheless criticized within both the academic sphere and the donor community. One of the problems is that some components overlap. This can contribute to certain coherence but is also confusing. The CPIA is one of the multiple data sources of the WGI, but The Bank staff also refers to the WGI in the building process of the CPIA (Devarajan and Jonhson, 2008). In the same vein, the Doing Business indicators guide the assessment of regulations during the rating process of the CPIA (cluster B). ${ }^{21}$.

As with any approach resulting from expert judgment evaluations, the procedure underlying the construction of indicators also raises critical comments. Some authors emphasize the potential arbitrariness accompanying the data collection, the weighting pattern of components, or the insufficient theoretical foundations of the CPIA (Van Waeyenberge, 2009; GTZ, 2008). In addition this indicator does not take into account the impact of structural vulnerability or the poverty of the human capital (Kanbur, 2005; Guillaumont 2009). The WGI are criticized for the lack of theory underlying the six components, as well as

\footnotetext{
${ }^{20}$ This includes "the process by which governments are selected, monitored and replaced; the capacity of the government to effectively formulate and implement sound policies; and the respect of citizens and the state for the institutions that govern economic and social interactions among them;".The initial team of the Governance Matters project was composed of Kaufmann, Kraay and Zoido-Lobaton, Mastruzzi replacing Zoido-Lobaton after the first edition.

${ }^{21}$ Arndt and Oman, 2006; Kaufmann and Kraay, 2008; Razafindrakoto and Roubaud, 2010; Devarajan and Jonhson, 2008; Williams and Siddique, 2008, Langbein and Knack, 2010).
} 
the tautology and weak discrimination of the governance aspects considered. As for the CPIA, the normative interpretation of components is not always clear, and all of them do not satisfy the orthogonality principle to provide a clear weighting pattern (Grindle, 2007; Andrews, 2008). For instance, Langbein and Knack (2010) argue that the different components of the WGI are narrowly related and tend to deliver the same message by using different words. Last but not least, the Doing Business database has some weaknesses (Arrunada, 2007; World Bank, 2008). The liberal conception of the market economy goes hand-in-hand with the potential excess of "shortermism", especially in the management of labour contracts ${ }^{22}$.

\section{The World Bank and the international donor community}

\section{What influences do bilateral and multilateral donors recognize?}

With the fall of the Berlin wall, some bilateral donors including the United States, put pressure on the Bank for more active support for political governance reforms. The bilateral delegation of powers to the Bank is associated with the so-called Buchanan's Samaritan Dilemma problem $(1975)^{23}$. Some donor countries have the will to maintain financial assistance to low income countries, but don't want to intervene themselves in those countries' economic and political reform agendas. The multilateral framework looks more appropriate for this purpose. But other motivations have been the will to promote an efficient coordination among the donor community through the Special Partnership for Africa (SPA), and the willingness to let the Bank go ahead and show the way.

When examining the position of the main bilateral donors on the governance issue, some discrepancies arise on the conception and the operationalization of aid policies. France's commitment to the new political governance paradigm goes back to the La Baule declaration, in 1990, and the France-Africa summit which was held in Ouagadougou, in 1996. The specific theme of this summit was: "good governance and development". Ten years later, governance criteria had entered somewhat in the aid allocation system. Traditional

\footnotetext{
${ }^{22}$ Indeed, among the most regular critics running counter Doing Business data, one could notify the bias in favor of formal and urban sectors, the oversight of recurrent transaction costs compared to initial costs, then the weakness in taking into account the substitution effect between present and future and the lack of distinction between deliberate procedure and restricting procedures (Arrunada, 2007).

${ }^{23}$ James M. Buchanan, "The Samaritan's Dilemma." in Edmund Prelim, ed., Altruism, Morality and Economic Theory (New York: Russell Sage, 1975), pp. 71-85.
} 
geographical distribution of France's financial flows are affected by an historical "path dependency" which proves to be a source of allocative inertia. Because of its former colonial power and its deep implications in the design of present cooperation, France faces difficulties in promoting a policy of rewarding good governance. However, in 2006, the French Ministry of economy joined the club of governance indicator producers, elaborating "institutional profiles" with the ambition of highlighting the main institutional factors that determine the economic take-off of successful countries. To refer to concepts we defined earlier, these profiles relate more to soft power (carrots) than hard power (stick). Part of the information produced by these profiles has recently been incorporated into the WGI. This incorporation can itself be interpreted as an expression of the Bank's smart power to develop attractiveness and stimulate appropriateness of its governance paradigm.

The United Kingdom's approach to governance differs somewhat from the French vision, as it relies on the development of a participatory-based assessment procedure. In other words, the assessment is jointly made with recipient countries. Through Drivers of Change (DOC) developed by DFID since 2003, governance starts with a political economy analysis which is quite comparable to the diagnostic surveys that the Bank implements on governance and anticorruption (GAC). Thus, the diagnostic of governance through a participatory process potentially increases the willingness to implement solutions (Chhotray and Hulme, 2009). Such an approach contrasts with that of the aggregate indicator where foreign aid is allocated across countries according to their international ranking. Beyond the DOC, aid allocation by the UK is also influenced by the Bank's CPIA rating system. This is especially true for fragile states where the governance issue is challenging because of overlapping exogenous constraints and endogenous political behavior ${ }^{24}$ (DFID, 2005).

The relationship between the USA and the World Bank reflects the complexity of the analysis when examining "soft" and "hard" powers of the organization. Some authors have talked about a hegemonic influence of USA on the way the World Bank perceives the governance issue (Wade, 2001, 2002; Stein, 2008, Weaver, 2008; Mikesell, 2001). But reciprocal influences do exist. Among the three channels of US aid only one seems to have been under the influence of the Bank's governance indicators. Indeed, six of the sixteen criteria underlying the Millennium Challenge Account (MCA) system are totally based on the World Bank governance indicators. Five come from the WGI and one from the Doing

\footnotetext{
${ }^{24}$ Yet, that leads to differences with the World Bank categorization of LICUS (Low Income Countries Under Stress) and has to face critics estimating that fragile states are defined following fragile criteria.
} 
Business project. While U.S Department of State funds are allocated according to strategic considerations, US-AID does not explicitly integrate governance criteria in its allocation formula, although this agency has undertaken governance assessments. Rather than social aspects, economic effectiveness and political considerations prevail in the design of the US governance agenda (Chhotray \& Hume, 2009).

The Japanese attitude is quite similar to the US position. Most scholars have shown that Japanese aid behavior is significantly influenced by the US aid system (Katada, 1997). Four different ministries participate in aid allocation, each of them pursuing different motives. Strategic considerations predominate in Latin America and Asia, the same main geographical areas as the USA. Accordingly, Japanese aid allocation is not explicitly based on "good" governance criteria, although some financing may be dedicated to governance related sectors, especially in Africa and Asia. By its multilateral aid contributions, Japan collaborates with the World Bank Institute, but also with the United Nations through the United Nations Democracy Fund.

With respect to our theme, the case of Nordic European countries is also interesting. Some authors consider that they are particularly sensitive to the "Samaritan Dilemma" (Hagen, 2006; Epstein and Gang, 2009). These countries delegate the management of significant parts of their aid to multilateral organizations, mainly the World Bank. In addition, as they are sensitive to question about governance, when providing non-delegated budget support, they prove to be influenced by the CPIA ratings. To a certain extent this behavior is also reflected in the behavior of the Dutch government (see Table 2).

Through the governance network (GovNet), the OECD-Development Assistance Committee (DAC) provides an opportunity for bilateral and multilateral donors to compare, discuss and coordinate views on governance in accordance with the Paris declaration on Aid Effectiveness and the Accra Agenda. On this specific issue, the 2009 OECD report gives the flavor and summarizes the different donor approaches (OECD, 2009).

Table 2 shows how donor governance assessments vary across countries and organizations. Some donors use one or more indicators, while others prefer the establishment of profiles; some incorporate quantitative indicators, while others refer to qualitative ones; some assessments are exclusively based on economic indicators, while others incorporate political economy judgments or measurements (OECD, 2009). The Bank's influence conveyed by indicators is indicated in the last column on the right. 
Table 2. The World Bank and governance assessments by some bilateral and multilateral partners

\begin{tabular}{|c|c|c|c|c|c|}
\hline Partners & Assessment tool denomination & $\begin{array}{l}\text { Data } \\
\text { type }\end{array}$ & $\begin{array}{c}\text { Governance } \\
\text { aspect }\end{array}$ & $\begin{array}{c}\text { Involvement of } \\
\text { the recipient } \\
\text { country }\end{array}$ & $\begin{array}{c}\text { Influence of } \\
\text { the World } \\
\text { Bank } \\
\text { indicator }\end{array}$ \\
\hline \multicolumn{6}{|c|}{ Multilateral Organizations } \\
\hline \multirow{2}{*}{ AfDB } & Country Governance Profile $(\mathrm{P})$ & QL & $\mathrm{E}$ & NS & WGI \\
\hline & CPIA (I) & QT & $\mathrm{E}$ & NS & CPIA \\
\hline \multirow[b]{2}{*}{ AsDB } & CPIA (I) & QT & $\mathrm{E}$ & NS & CPIA \\
\hline & $\begin{array}{c}\text { Governance Risk Assessment and Risk } \\
\text { management (I) }\end{array}$ & QL & $\mathrm{E}$ & $S$ & - \\
\hline EC-EDF & Governance profiles $(\mathrm{P})$ & QT-QL & $\mathrm{E}$ & NS & WGI \\
\hline \multirow{2}{*}{ IaDB } & $\begin{array}{c}\text { Country Institutional and Policy } \\
\text { Evaluation-CIPE - (I) }\end{array}$ & QT & $\mathrm{E}$ & NS & CPIA \\
\hline & $\begin{array}{l}\text { Democratic Governance and } \\
\text { Institutional Assessment }(\mathrm{P})\end{array}$ & QT-QL & P-E & $S$ & - \\
\hline \multicolumn{6}{|c|}{ Bilateral Donors } \\
\hline France & Institutional profiles (I) & QT & $\mathrm{E}$ & NS & WGI \\
\hline Germany & $\begin{array}{c}\text { Catalogue of criteria: assessing } \\
\text { development orientation (I) }\end{array}$ & QL & $\mathrm{E}$ & NS & CPIA, WGI \\
\hline \multirow[t]{2}{*}{ Netherlands } & $\begin{array}{c}\text { Strategic governance and corruption } \\
\text { analysis }(\mathrm{P})\end{array}$ & QL & P-E & NS & CPIA \\
\hline & Stability Assessment Framework (P) & QL & P-E & NS & - \\
\hline \multirow{3}{*}{$\begin{array}{l}\text { United } \\
\text { Kingdom }\end{array}$} & Country Governance Assessment (I) & QT-QL & $\mathrm{E}$ & NS & WGI \\
\hline & Drivers of change $(\mathrm{P})$ & QL & P-E & $\mathrm{S}$ & - \\
\hline & Strategic Conflict Assessment (I) & QL & P-E & NS & CPIA \\
\hline \multirow{2}{*}{$\begin{array}{l}\text { United States } \\
\text { of America }\end{array}$} & MCA (I) & QT & E & NS & WGI, DB \\
\hline & $\begin{array}{l}\text { USAID-Democracy and Governance } \\
\text { Strategic Assessment Framework (P) }\end{array}$ & QL & P-E & NS & WGI \\
\hline
\end{tabular}

Note : $\mathrm{I}=$ indicator and $\mathrm{P}=$ profile. For the row data type: $\mathrm{QL}=$ qualitative and $\mathrm{QT}=$ quantitative. For the row Governance aspect: $\mathrm{E}=$ economic and $\mathrm{P}-\mathrm{E}=$ political economy. For the row host country involvement: $\mathrm{S}=$ significant participation and $\mathrm{NS}=$ non significant participation. $\mathrm{DB}=$ doing business. $\mathrm{EC}-\mathrm{EDF}=$ European Commission/European Development Fund; AfDB = African Development Bank; AsDB = Asian Development Bank; IaDB = Inter-American Development Bank.

Sources : From OECD (2009) and authors'compilations, various national documents

Through the European Development Fund (EDF), the European Commission (EC), which is the largest worldwide grant provider, included "good" governance as an essential element of the Cotonou Agreement. In the preamble of this 2000 document, the parties acknowledge the critical importance of a political environment that is conducive to development, as well as the primary responsibility of the ACP countries for creating such an environment. This 
explains why ACP-EU cooperation is underpinned by a basic set of political principles and values that each of the parties is supposed to respect. The rules of the game include three "essential" elements (i.e., respect for human rights, democratic principles and the rule of law) and one "fundamental" element (i.e. good governance). The violation of these principles may lead to partial or complete suspension of development cooperation. In 2006, the Thematic Evaluation of the EC support to Good Governance (EC, 2006) and later on the ACP governance profiles re-stated the EC interest for this subject. The World Bank exerts a notable influence on the EC governance profiles, notably through its WGI which are considered along with three other clusters. These clusters take into account the social aspect of governance, the regional and international context, and the quality of the partnership. The Bank also influences regional multilateral banks, mainly through the CPIA as these organizations may be reluctant to consider the political dimension of member states.

\section{Beyond rhetoric: what do correlations suggest?}

A deep analysis addressing the orientation of the causality between donors' aid allocations and WB governance indicators is beyond the scope of this sub-section. Our ambition here is limited to shedding light on potential linear correlations. Annual new aid commitments as published by DAC/OECD are the left hand side variable of the regression model we run. Commitments are preferred to disbursements, which are more likely to be determined by the nature of projects (e.g. the difficulty of stopping a multi-annual project because of "bad" governance).

Cross-sectional estimations are run, the number of observations being determined by the availability of data for the three WB indicators. The first official disclosure of the CPIA dates back to 2005. Average values over the period 2005-2008 are considered for all the variables to smooth the short time series. On the left side of table 3, donor-based correlation models are presented. We begin with a basic empirical model reflecting the WB's Performance-Based Allocation system (PBA) from which we drop out any influence of governance indicators ${ }^{25}$. Aid is assumed to be linked to the same allocation model, with population and the per capita Gross National Income as determinants. The square of these variables is also considered, to control for non-linearity of relationships. The potential financial risks, or the country portfolio

25 Denmark and Japan have been considered in table 3 while these countries are outside the OECD source we used to build table 2. On the contrary, the Inter-American Development Bank is absent from table 3 for statistical reasons -information about new commitments over the period 2005-2008 is not available for this regional Bank. 
performance, are proxied by the external debt service ratio. For France and the United Kingdom, a dummy variable has also been introduced reflecting historical relations with former colonial territories (see Alesina and Dollar, 2000). For each donor, the common basic econometric model (BM) highlights the goodness of fit (e.g. coefficient of determination). By using nested hypotheses, the model is then augmented to see how new commitments during the period correlate with the WB's indicators. The CPIA is embedded first to the basic model (BM), and then, the six components of the WGI and finally, the Doing Business rankings. Adjusted coefficients of determination $\left(\mathrm{R}^{2} \mathrm{adj}\right)$ and partial F-tests indicate the statistical contribution of additional variables to the explanation of the variance of aid allocation.

Table 3. World Bank governance indicators and aid allocation (2005-2008)

\begin{tabular}{|c|c|c|c|c|c|c|c|c|c|}
\hline & & & & & World & ank gov & nance indic & tors & \\
\hline Basic econon & tric model & & & & & & & & \\
\hline Without WB & governance & ators & & BM & PIA & $\mathbf{B M}+\mathbf{C}$ & $\mathbf{I A}+\mathbf{W G I}$ & $\begin{array}{r}\mathbf{B M}+ \\
\mathbf{W G}\end{array}$ & $\begin{array}{l}\text { PIA+ } \\
\text { DB }\end{array}$ \\
\hline Donors & $\begin{array}{l}\text { Number of } \\
\text { Countries }\end{array}$ & $\mathbf{R}^{2}$ adj & F-test & $\mathbf{R}^{2}$ adj & $\begin{array}{c}\text { Partial } \\
\text { F-test }\end{array}$ & $\mathbf{R}^{2} \mathbf{a d j}$ & $\begin{array}{l}\text { Partial F- } \\
\text { test }\end{array}$ & $\mathbf{R}^{2}$ adj & $\begin{array}{l}\text { Partial } \\
\text { F-test }\end{array}$ \\
\hline IDA (WB) & 70 & 0.45 & 21.7 *** & 0.72 & $57.5 * * *$ & 0.75 & $2.4 * *$ & 0.75 & 0.8 \\
\hline AfDB & 31 & 0.63 & $43.5 * * *$ & 0.82 & $15.8 * * *$ & 0.81 & 1.3 & 0.80 & 0.3 \\
\hline AsDB & 17 & 0.61 & $11.7 * * *$ & 0.68 & $5.7 * *$ & 0.64 & 3.5 & 0.69 & 1.9 \\
\hline EDF (EC) & 68 & 0.55 & $28.4 * * *$ & 0.55 & 1.5 & 0.58 & $3.9 * * *$ & 0.59 & $4.1^{* *}$ \\
\hline Denmark & 45 & 0.21 & $5.2 * * *$ & 0.23 & $3.0^{*}$ & 0.22 & 0.9 & 0.22 & 1.0 \\
\hline France $\star$ & 64 & 0.58 & $18.2^{* * * *}$ & 0.57 & 0.1 & 0.55 & 1.1 & 0.56 & 1.3 \\
\hline Germany & 67 & 0.70 & $74.8^{* * *}$ & 0.72 & $5.0^{* * *}$ & 0.74 & $2.2 *$ & 0.73 & 0.2 \\
\hline Japan & 65 & 0.61 & $26.3^{* * *} *$ & 0.67 & $18.1 * * *$ & 0.69 & $2.9^{* *}$ & 0.69 & $5.6^{* * *}$ \\
\hline Netherlands & 56 & 0.19 & $6.6^{* * *}$ & 0.28 & $6.5^{* *}$ & 0.35 & $4.0 * * *$ & 0.35 & $4.0^{*}$ \\
\hline $\begin{array}{l}\text { United } \\
\text { Kingdom } \star\end{array}$ & 62 & 0.69 & $35.3^{* * * *}$ & 0.71 & $3.3^{*}$ & 0.69 & 0.6 & 0.71 & $5.1 * *$ \\
\hline $\begin{array}{l}\text { United States of } \\
\text { America }\end{array}$ & 67 & 0.59 & $28.8 * * *$ & 0.60 & $3.0^{*}$ & 0.61 & 1.7 & 0.61 & 0.2 \\
\hline
\end{tabular}

Notes: For each of the donor-based correlation models, the log of average ODA commitments over the period 2005-08 are considered on the left hand side. In the basic model we account for: GNI per capita and the square of this variable, population and its square, and external debt service. For France and the UK a dummy variable is also introduced $(\star)$ reflecting past colonial status. $* * * \mathrm{p}<0.01, * * \mathrm{p}<0.05, *$ p $<0.1$. Aid data come from OECD/DAC online database while governance and the other variables are provided by the World Bank's WDI, 2009.

The basic model suggests a level of correlation with aid commitments varying from 19\% (Netherlands) to 70\% (Germany) over the period 2005-2008. The introduction of the CPIA significantly increases these correlations, especially for the World Bank (IDA), and to a lesser extent for the regional multilateral development banks (AfDB, AsDB). Although the role of the CPIA varies a lot across bilateral donors, diversity seems to prevail in accordance with what official policies tell us (table 2). This indicator is influential for the 
Netherlands (+7 percentage points) and Japan (+6) while its impact proves marginal for other donors including the European Commission. For the United Kingdom and France, the past colonial history has been introduced in the regression under the form of a dummy variable for countries having the status of a former colony. For France, this dummy variable gives more information on the rules for aid allocation than any other structural determinant or governance indicator. In other words, with this specification, the adjusted coefficient of determination $\left(\mathrm{R}^{2} \mathrm{adj}\right.$ ) rises from $18 \%$ to $58 \%$. To a lesser extent this finding also applies to the UK (from $055 \%$ to $69 \%$ ). France is characterized by a strong "path dependency", its assistance being concentrated on its priority solidarity zone (ZSP). This zone overlaps with Sub-Saharan African countries whose structural vulnerability negatively affects the quality of the public management. Accordingly, although France is engaged in the promotion of "good governance", the relation between aid commitments and WB indicators proves weaker than for other bilateral donors.

Do the WGI or Doing Business provide additional information about aid allocation rules? The World Bank's aid proves sensitive to the WGI, as is that of the European Commission and the Netherlands, but regional multilateral bank aid is not. In the case of AfDB or AsDB, member countries are also shareholders of these organizations. This institutional situation may introduce acute difficulties in the assessment of the political context, especially for Africa, as the rules of liberal democracy still remain to be settled. Last but not least, the Doing Business indicators are correlated to aid commitments only for the AsDB.

\section{CONCLUSION}

The World Bank's model of "good" governance has been developed over several decades since the end of the 1970s. The normative concept comes from the liberal philosophical tradition, combining the protection of private property, the consent of the governed, and the prevalence of legislative power rather than autocratic forms of rule. The present state of art can be seen as inherited from the age of Enlightenment, but in the eighteenth century, the political dimension had an importance which entered belatedly into the Bank's concept, for historical reasons. In shaping what good governance means, the organization has had to comply with its founding Articles of Agreement as well as some ideological barriers. With the fall of communism some authors thought that universal values of liberalism would spread worldwide, allowing the unity of both political and economic governance aspects in 
accordance with some liberal philosophers such as Rawls or Dworkin. A long term evolution covering three decades underlies the governance indicators that have been elaborated within the Bank. These indicators focused first on economic aspects (CPIA, Doing Business), and later embraced the political (WGI) dimension of the social liberal contract.

In the design and the worldwide spread of what might be understood as good governance, the Bank and the academic spheres geographically close to its headquarters played a significant role, especially but not exclusively, through publications. This article has made a census of the Bank's publications by using the Web of Science bibliographic database from the ISI Web of Knowledge website. The worldwide publications on governance have dramatically and steadily increased to reach 800 in 2008. Within this production, the Bank's share has varied from less than $1 \%$ to more than $3 \%$. Within the knowledge production of the Bank, publications on governance have represented an annual maximum of $8 \%$ over the period 2005-08, but with a peak of $25 \%$ in 2003-04. This was calculated using a manual counting procedure from ten academic economics journals among the most important worldwide. So the Bank's message on governance circulated in academia, suggesting a deliberate search for a qualitative effect, using knowledge production as an effective channel to strengthen the influence of the organization.

As well as publications, training and learning activities were also important, as were the elaboration and calculation of the governance indicators we referred to. In shaping the concept of "good" governance, the Bank combined both soft and hard power. Soft power comes from the Bank's ability to develop the attractiveness of liberal society values and its concomitant welfare implications; to keep developing countries open to the process of integration into the world economy; and to promote poverty reduction strategies as a top priority. The Bank's soft power is required to manage the diversity of the world; to keep partners on board; and to maintain relationships with all the stakeholders including NGOs, and international civil society at large. But hard power also matters through the performancebased financial system which links aid to the "good" governance objectives as measured, by the CPIA or the WGI. The relationship between the three WB indicators and the new commitments of some of the most important donors has been tested on donor-based crosssectional relationships for the period 2005-2008. The statistical framework does not allow a rigorous conclusion in terms of causal inference. However, most of the regressions we run did not reject significant correlations, in accordance with what donors recognize, including when the regression model controls for a vector of structural determinants of aid allocation. 
The CPIA proves to be closely correlated with aid from both the Bank and the regional multilateral banks, while the political dimension of governance prevails for the European Commission. Former colonial countries such as France, and to a lesser extent the UK, seem to pay less attention to the governance issue. Some geostrategic reasons surely underlie their behavior, as well as the fact that governance is not independent of the sources of structural vulnerability which go hand-in-hand with poverty in former sub-Saharan African colonies.

\section{REFERENCES}

Alesina, A. and D. Dollar, (2000). Journal of Economic Growth, Springer, vol. 5(1), 33-63, March.

Andrews, M (2008). The good governance agenda: Beyond indicators without theory, Oxford Development Studies, vol 36, $\mathrm{n}^{\circ}$ 4, 379-408

Arndt, C. and C. Oman, (2006) Uses and Abuses of Governance Indicators, OECD, Paris.

Arrunada, B. (2007). Pitfalls to avoid when measuring institutions: Is Doing Business damaging business? Journal of Comparative Economics, vol. 35(4), pp. 729-747,

Banerjee, A., A. Deaton, N. Lustig, and K. Rogoff, (2006). An Evaluation of World Bank Research, 1998 - 2005, September, World Bank Washington DC

Brautigam, D. (1991) Governance and Economy: A Review, The World Bank policy research working paper 815 .

Burnside, C. and D. Dollar (2000) Aid, Policies, and Growth. American Economic Review, Vol. 90, No. 4, pp. 847-868.

Cling, J.P. and F. Roubaud (2008). La Banque Mondiale, Collection REPERES, Ed. La Découverte.

Chhotray, V. and D. Hulme (2009). Contrasting Visions for Aid and Governance in the 21st Century: The White House Millennium Challenge Account and DFID's Drivers of Change, World Development Vol. 37, No. 1, pp. 36-49.

European Commission -EC (2006) Thematic Evaluation of the European Commission support to Good Governance; Brusels, Belgium.

Das, T. (2009) The information and financial power of the World Bank: knowledge production through UN collaboration; Progress in Development Studies; 9; 209

Devarajan, S., and S.Johnson (2008). Two Comments on "Governance Indicators: Where Are We, Where Should We Be Going?" by Daniel Kaufmann and Aart Kraay, The World Bank Research Observer, vol. 23, no. 1.

DFID (2005). Why we need to work more effectively in fragile states, published by the Department of International Development.

Duffield, M (2002) Social reconstruction and the radicalization of development: Aid as a relation of global liberal governance, Development and Change 33 (5):1049-1071

Epstein, G. S. and I. N. Gang, (2009) Good governance and good aid allocation. Journal of Development Economics 89, pp 12-18.

Fisher, S.,(1995). The IMF and the World Bank at Fifty, in H. Genberg (ed), The International Monetary System. Heidelberg: Springer-Verlag, 171-200.

Fukuyama, F. (1992) The End of History and the Last Man; Free Press

Gavin, M. and D. Rodrik (1995). The World Bank in Historical Perspective, The American Economic Review, Vol. 85, No. 2, (May, 1995), pp. 329-334 
Gilbert, C., A. Powell, and D. Vines (1999). Positioning the World Bank, The Economic Journal, Vol. 109, No. 459, Features, pp. F598-F633

Grindle, M.S. (2007) Good Enough Governance Revisited, Development Policy Review, 25 (5): $553-574$

GTZ (2008) Adaptation and Refinement of the World Bank's "Country Policy and Institutional Assessment" (CPIA). Discussion Paper.

Guillaumont, P. (2009). "An Economic Vulnerability Index: Its Design and Use for International Development Policy", Oxford Development Studies, Vol. 37, n 3, p. 193 228. September.

Guillaumont, P., and L. Chauvet (2001). Aid and performance: a reassessment. Journal of Development Studies, 37(6), 66-92.

Hagen, R. J. (2006) Samaritan agents? On the strategic delegation of aid policy. Journal of Development Economics 79, 249-263.

Harrison, G. (2005) The World Bank, Governance and Theories of Political Action in Africa, British Journal of Politics \& International Relations, Vol 7, 240-260.

Huntington, S. P., (1993). The Clash of Civilizations? Foreign Affairs, vol. 72, n. 3, 22-49.

Joseph, J.W. (2000) Stasis and Change in the IMF and World Bank: International Context and Institutional Dynamics, The Social Science Journal, Volume 37, Number 1, 43-66.

Kanbur, R. (2005) "Reforming the Formula: A Modest Proposal for Introducing Development Outcomes in IDA Allocation Procedures", January, 2005. Revised version published in Revue d'Economie du Developpement, 2005.

Kapur, D., J. P. Lewis, R. Webb, (1997). The World Bank - Its First Half. Century, Vol. 1, Brookings Institution Press, Washington, D.C.

Katada, S.N. (1997) Two Aid Hegemons: Japanese-US Interaction and Aid Allocation to Latin America and the Caribbean, World Development, Vol. 25 No. 6, 931-45

Kaufmann, D., A. Kraay, P. Mastruzzi (2008) Governance Matters VII: Governance Indicators for 1996-2007; World Bank Policy Research Working Paper No. 4654.

Kaufmann, D. and A. Kraay (2008) Governance Indicators: Where Are We, Where Should We Be Going? World Bank Research Observer 23(1): 1-30.

Krueger, A.O. (1998) Whither the World Bank and the IMF? Journal of Economic Literature, Vol. 36, No. 4, 1983-2020.

Langbein, L , S. Knack (2010) The Worldwide Governance Indicators: Six, One, or None? Journal Of Development Studies 46 (2):350-70

Mawdsley, E. and J. Rigg (2003) The World Development Report II: continuity and change in development orthodoxies, Progress in Development Studies; 3; 271

McNeill, D. (2006) The Diffusion of Ideas in Development Theory and Policy; Global Social Policy; 6; 334

Mehta, L. (2001) The World Bank and Its Emerging Knowledge Empire; Human Organization; Volume 60, Number 2; 189-96

Mikesell, R. F., (2001). The Meltzer Commission Report on International Institutions Reviewed work(s): Report of the International Financial Institutions Advisory Commission by Allan Meltzer. Economic Development and Cultural Change, Vol. 49, No. 4 Jul., 883-94.

Miller-Adams, M. (1999) The World Bank: new agendas in a changing world, Routledge

Mosley, P. J. Harrigan, and F.J Toye.(1995) Aid and power: the World Bank and policybased lending, Routledge, vol 1.

Nye, J.S (1990) Bound to Lead: The Changing Nature of American Power, New York, Basic Books.

OECD (2009). Donor Approaches to Governance Assessments, Sourcebook, Paris. 
Onis, Z and F. Senses (2005) Rethinking the emerging Post-Washington Consensus. Development And Change 36 (2):263-290

Owusu, F (2003) Pragmatism and the Gradual Shift from Dependency to Neoliberalism: The World Bank, African Leaders and Development Policy in Africa? World Development Vol. 31, No. 10, pp. 1655-1672

Pender, J. (2001) From 'Structural Adjustment' to 'Comprehensive Development Framework': Conditionality Transformed? Third World Quarterly, Vol. 22, No. 3, pp. 397-411.

Plehwe, D. (2007) A Global Knowledge Bank? The World Bank and Bottom-Up Efforts to Reinforce Neoliberal Development Perspectives in the Post-Washington Consensus Era. Globalizations, Volume 4, Issue 4, $514-528$.

Razafindrakoto, M and F. Roubaud (2010) Are International Databases on Corruption Reliable? A Comparison of Expert Opinion Surveys and Household Surveys in SubSaharan Africa. World Development Vol. 38, No. 8, pp. 1057-1069,

Rodrik, D. (2006) Goodbye Washington Consensus, Hello Washington Confusion? A Review of the World Bank's Economic Growth in the 1990s: Learning from a Decade of Reform. Journal of Economic Literature, Vol. XLIV

Santiso, C. (2001). Good Governance and Aid Effectiveness: The World Bank and Conditionality. Georgetown Public Policy Review, 7(1), 1-22.

Shihata, I. (1995) World Bank in a Changing World: selected essays and lectures. Martinus Nijoff publishers, La Hayes/Londres/Boston

Squire, L. (1999). Why the World Bank should be involved in development research, mimeo, World Bank, Washington DC, in C.L Gilbert and L.Vines.

Stein, H., (2008). Beyond The World Bank Agenda: an institutional approach to development. The University of Chicago Press.

Stern, N. and F. Ferreira(1997) 'The World Bank as "Intellectual Actor" ', in D. Kapur, J. P. Lewis and R. Webb (eds) The World Bank: Its First Half Century, Washington, DC: Brookings Institution Press, Vol. 2, Chapter. 12, pp. 523609.

Stiglitz, J.E (1999) The World Bank at the Millennium. The Economic Journal, Vol. 109, No. 459, pp. F577-F597

Stone, D and C. Wright, (2007) The World Bank and governance: a decade of reform and reaction, Routledge.

Storey, A. (2000) The World Bank, Neo-Liberalism, and Power: Discourse Analysis and Implications for Campaigners, Development in Practice, Vol. 10, No. 3/4, pp. 361 -370

Tshuma, L. (1999) The Political Economy of the World Bank's Legal Framework for Economic Development, Social Legal Studies; 8; 75

Van Waeyenberge, E. (2009) Selectivity at Work: Country Policy and Institutional Assessments at the World Bank. The European Journal of Development Research, vol. 21 , issue 5 , pages 792-810.

Wade, H. R (2001) Making the World Development Report 2000: attacking poverty, World Development; vol 29 n 8 , pp 1435 - 1441.

Wade, R. H. (2002). US Hegemony and the World Bank: The Fight over People and Ideas, Review of International Political Economy, Vol. 9, No. 2., pp. 201-229.

Weaver, C. (2008) Hypocrisy Trap: The World Bank and the Poverty of Reform; Princeton University Press

Williams, A. and A. Siddique (2008) The use (and abuse) of governance indicators in economics: a review. Economics of Governance 9:131-175

Williams, D., T. Young (1994). Governance, the World Bank and Liberal Theory. Political Studies 42 (1), pp. 84-100.

World Bank (1981). Accelerated development in Sub-Saharan Africa: an agenda for action; Washington DC. 
World Bank (1989). Sub-Sahara Africa: from crisis to sustainable growth. Washington DC.

World Bank (1992). Governance and Development, Washington DC.

World Bank (1994). Governance : the World Bank experience, Washington DC.

World Bank (1997) World Development Report: the State in a changing world. Washington DC.

World Bank (1998). Assessing aid: What Works, What Doesn't, and Why, Washington DC.

World Bank (2001a) Review of Governance - The Critical Factor, The World Bank operation evaluation-IDA Review. Washington D.C.

World Bank (2001b) World Development Report: Building institutions for markets. Washington, D.C.

World Bank (2006). World Development Report: Equity and development, Washington DC.

World Bank (2008). Doing Business: an independent evaluation. Taking the Measure of the World Bank-IFC Doing Business Indicators ; Washington DC.

World Bank (2009) Doing Business 2010 : Reforming through difficult times. Washington DC.

World Bank (2010) IDA's Performance Based Allocation System: Review of the Current System and Key Issues for IDA16 http://siteresources.worldbank.org/IDA/Resources/Seminar PDFs/73449$\underline{1271341193277 / \text { PBAIDA16.pdf }}$ 


\begin{tabular}{|c|c|c|c|c|c|c|c|c|c|c|c|c|c|c|c|c|}
\hline & (1) & (2) & (3) & (5) & (6) & (7) & (8) & (9) & (10) & (11) & (12) & (13) & (14) & (15) & (16) & (17) \\
\hline VARIABLES & IDA & IDA & IDA & IDA & EC & EC & EC & EC & AFDB & AFDB & AFDB & AFDB & ASDB & ASDB & ASDB & ASDB \\
\hline \multicolumn{17}{|c|}{ Basic econometric model } \\
\hline \multirow[t]{2}{*}{ GNI pc } & $\begin{array}{l}-0.104 \\
(2.521)\end{array}$ & $\begin{array}{l}1.527 \\
(2.153)\end{array}$ & $\begin{array}{l}-0.210 \\
(2.144)\end{array}$ & $\begin{array}{l}-0.355 \\
(2.196)\end{array}$ & $\begin{array}{l}4.750 \text { *** } \\
(1.049)\end{array}$ & $\begin{array}{l}4.514 * * * \\
(1.046)\end{array}$ & $\begin{array}{l}5.249 * * * \\
(1.158)\end{array}$ & $\begin{array}{l}-5.177 * * * \\
(1.127)\end{array}$ & $\begin{array}{l}-0.0979 \\
(1.796)\end{array}$ & $\begin{array}{l}-0.560 \\
(1.385)\end{array}$ & $\begin{array}{l}-1.210 \\
(1.746)\end{array}$ & $\begin{array}{l}-1.282 \\
(1.786)\end{array}$ & $\begin{array}{l}25.10 * * \\
(8.359)\end{array}$ & $\begin{array}{l}35.54 * * * \\
(8.277)\end{array}$ & $\begin{array}{l}62.47 * * \\
(14.57)\end{array}$ & $\begin{array}{l}75.41^{* *} \\
(17.56)\end{array}$ \\
\hline & & & & & & & & & & & & & & - & & \\
\hline \multirow[t]{2}{*}{ GNI pc^2 } & 0.0948 & -0.0956 & 0.0463 & 0.0526 & $0.374 * * *$ & $0.349 * * *$ & $0.413 * * *$ & $0.416^{* * *}$ & 0.0617 & 0.0621 & 0.125 & 0.131 & $-1.899 * *$ & $2.745^{* * *}$ & $-4.739 * *$ & $-5.733 * *$ \\
\hline & $(0.183)$ & $(0.163)$ & $(0.164)$ & $(0.167)$ & $(0.0861)$ & $(0.0866)$ & $(0.0934)$ & $(0.0898)$ & $(0.157)$ & $(0.121)$ & $(0.145)$ & $(0.147)$ & $(0.641)$ & $(0.642)$ & $(1.067)$ & $(1.312)$ \\
\hline \multirow[t]{3}{*}{ POP } & $0.966^{* * * *}$ & $0.681 * * *$ & $1.076^{* * *}$ & $1.079 * * *$ & $0.745 * * *$ & $0.710 * * *$ & $0.857 * * *$ & $0.867 * * *$ & $1.022 * * *$ & $0.926 * * *$ & $0.907 * * *$ & $0.926 * * *$ & -0.0559 & -0.303 & 0.879 & 0.568 \\
\hline & $(0.301)$ & $(0.199)$ & $(0.208)$ & $(0.219)$ & $(0.141)$ & $(0.147)$ & $(0.153)$ & $(0.146)$ & $(0.279)$ & $(0.248)$ & $(0.290)$ & $(0.309)$ & $(0.466)$ & $(0.447)$ & $(0.932)$ & $(0.903)$ \\
\hline & & & & & - & - & - & & & & & & & & & \\
\hline \multirow[t]{2}{*}{$\mathrm{POP}^{\wedge} \mathbf{2}$} & 0.012 & 0.018 & -0.029 & -0.029 & $0.044 * * *$ & $0.043 * * *$ & $0.053 * * *$ & $-0.054 * * *$ & 0.0040 & -0.046 & -0.042 & -0.046 & $0.124 *$ & $0.115^{*}$ & 0.040 & 0.069 \\
\hline & $(0.0380)$ & $(0.0399)$ & $(0.0515)$ & $(0.0512)$ & $(0.0151)$ & $(0.0147)$ & $(0.0179)$ & $(0.0153)$ & $(0.0585)$ & $(0.0505)$ & $(0.0529)$ & $(0.0569)$ & $(0.0631)$ & $(0.0555)$ & $(0.0856)$ & $(0.0805)$ \\
\hline \multirow[t]{2}{*}{ DEBT Service } & -0.136 & -0.0670 & -0.0719 & -0.0520 & -0.139 & -0.131 & $-0.198^{*}$ & $-0.231 * *$ & $-0.370 * *$ & -0.115 & -0.184 & -0.188 & -0.0776 & 0.113 & -0.196 & -0.144 \\
\hline & $(0.309)$ & $(0.174)$ & $(0.150)$ & $(0.156)$ & $(0.125)$ & $(0.124)$ & $(0.100)$ & $(0.106)$ & $(0.162)$ & $(0.104)$ & $(0.117)$ & $(0.113)$ & $(0.318)$ & $(0.364)$ & $(0.581)$ & $(0.510)$ \\
\hline \multicolumn{17}{|c|}{ World Bank governance indicators } \\
\hline \multirow[t]{2}{*}{ CPIA } & & $2.408 * * *$ & $1.629 * * *$ & $1.557 * * *$ & & 0.230 & 0.0119 & 0.109 & & $1.162 * * *$ & $1.289^{* *}$ & $1.248^{* *}$ & & $1.790 * *$ & $4.513^{*}$ & 5.261 \\
\hline & & $(0.317)$ & $(0.482)$ & $(0.497)$ & & $(0.188)$ & $(0.413)$ & $(0.413)$ & & $(0.291)$ & $(0.570)$ & $(0.559)$ & & $(0.749)$ & $(2.049)$ & $(3.103)$ \\
\hline \multirow[t]{2}{*}{ WGI_Corruption } & & & -0.511 & -0.336 & & & 0.114 & -0.136 & & & $-1.032 *$ & -0.926 & & & 3.894 & 3.394 \\
\hline & & & $(0.506)$ & $(0.492)$ & & & $(0.261)$ & $(0.257)$ & & & $(0.526)$ & $(0.610)$ & & & $(2.412)$ & $(2.796)$ \\
\hline \multirow[t]{2}{*}{ WGI_Government } & & & 0.480 & 0.388 & & & -0.115 & 0.0137 & & & 0.376 & 0.348 & & & -8.703 & -9.618 \\
\hline & & & $(0.871)$ & $(0.857)$ & & & $(0.579)$ & $(0.584)$ & & & $(0.543)$ & $(0.570)$ & & & $(6.007)$ & $(6.884)$ \\
\hline \multirow[t]{2}{*}{ WGI_Stability } & & & 0.347 & 0.405 & & & -0.00848 & -0.0859 & & & -0.00983 & 0.0102 & & & 0.336 & 0.173 \\
\hline & & & $(0.333)$ & $(0.325)$ & & & $(0.170)$ & $(0.172)$ & & & $(0.195)$ & $(0.211)$ & & & $(0.529)$ & $(0.539)$ \\
\hline \multirow[t]{2}{*}{ WGI_Law } & & & 0.399 & 0.254 & & & -0.450 & -0.257 & & & 0.605 & 0.524 & & & 1.185 & 2.008 \\
\hline & & & $(0.549)$ & $(0.549)$ & & & $(0.280)$ & $(0.241)$ & & & $(0.606)$ & $(0.662)$ & & & $(0.968)$ & $(0.905)$ \\
\hline \multirow[t]{2}{*}{ WGI_Regulatory } & & & -0.436 & -0.440 & & & 0.0738 & 0.0785 & & & 0.0577 & 0.0322 & & & 0.0705 & 0.297 \\
\hline & & & $(0.480)$ & $(0.474)$ & & & $(0.432)$ & $(0.438)$ & & & $(0.607)$ & $(0.602)$ & & & (1.778) & $(1.445)$ \\
\hline \multirow[t]{2}{*}{ WGI_Voice } & & & $0.720 * *$ & $0.696^{* *}$ & & & $0.686 * * *$ & $0.726 * * *$ & & & -0.350 & -0.351 & & & 0.434 & 0.793 \\
\hline & & & $(0.320)$ & $(0.317)$ & & & $(0.183)$ & $(0.178)$ & & & $(0.223)$ & $(0.235)$ & & & $(0.524)$ & $(0.727)$ \\
\hline \multirow[t]{2}{*}{ DB rank } & & & & -0.00418 & & & & $0.00574 * *$ & & & & -0.00184 & & & & 0.0126 \\
\hline & & & & $(0.00472)$ & & & & $(0.00284)$ & & & & $(0.00341)$ & & & & $(0.00910)$ \\
\hline Observations & 71 & 71 & 70 & 70 & 69 & 69 & 68 & 68 & 31 & 31 & 31 & 31 & 18 & 18 & 17 & 17 \\
\hline Adj R-squared & 0.453 & 0.723 & 0.751 & 0.750 & 0.553 & 0.554 & 0.581 & 0.596 & 0.637 & 0.820 & 0.810 & 0.801 & 0.619 & 0.686 & 0.645 & 0.696 \\
\hline
\end{tabular}

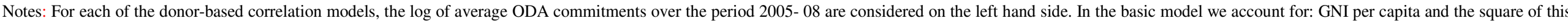

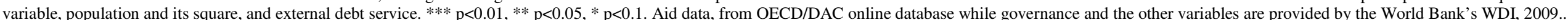


CERDI, Etudes et Documents, E 2011.27

\begin{tabular}{|c|c|c|c|c|c|c|c|c|c|c|c|c|c|c|c|c|}
\hline & (18) & (19) & (20) & (21) & (22) & (23) & (24) & (25) & (26) & (27) & (28) & (29) & (30) & (31) & (32) & (33) \\
\hline Basic model & JAPAN & JAPAN & JAPAN & JAPAN & USA & USA & USA & USA & UK & UK & UK & UK & FRANCE & FRANCE & FRANCE & FRANCE \\
\hline \multirow[t]{2}{*}{ GNI pc } & 2.16 & $3.00^{*}$ & 1.69 & 1.87 & -3.17 & -2.63 & -2.54 & -2.57 & $-5.81^{* * * *}$ & $-5.47 * * *$ & $-6.13^{* * *}$ & $-6.77^{* * * *}$ & -2.65 & -2.59 & -2.85 & -2.51 \\
\hline & (1.64) & (1.58) & (1.43) & (1.33) & $(1.96)$ & (1.81) & (1.80) & (1.85) & (1.82) & (1.81) & $(2.09)$ & (2.05) & $(2.23)$ & $(2.25)$ & $(2.26)$ & $(2.21)$ \\
\hline \multirow[t]{2}{*}{$\mathrm{GNI} \mathrm{pc}^{\wedge} 2$} & -0.141 & $-0.231^{*}$ & -0.122 & -0.153 & $0.295^{*}$ & 0.238 & 0.236 & 0.234 & $0.45 * * *$ & $0.41 * * *$ & $0.466 * *$ & $0.501^{* * *}$ & 0.218 & 0.211 & 0.239 & 0.225 \\
\hline & $(0.133)$ & $(0.128)$ & $(0.117)$ & $(0.109)$ & $(0.161)$ & $(0.149)$ & $(0.147)$ & $(0.153)$ & $(0.15)$ & $(0.15)$ & $(0.17)$ & $(0.17)$ & $(0.18)$ & $(0.184)$ & $(0.189)$ & $(0.183)$ \\
\hline \multirow[t]{2}{*}{ POP } & $0.427^{* * *}$ & $0.306^{*}$ & $0.491 * * *$ & $0.469 * *$ & $1.252^{* * * *}$ & $1.171 * * *$ & $1.07 * * *$ & $1.073^{* * * *}$ & $0.94 * * *$ & $0.88 * * *$ & $0.81 * *$ & $0.90^{* * * *}$ & 0.29 & 0.277 & 0.338 & 0.392 \\
\hline & $(0.177)$ & $(0.156)$ & $(0.182)$ & $(0.179)$ & $(0.192)$ & $(0.185)$ & $(0.210)$ & $(0.213)$ & $(0.278)$ & $(0.263)$ & $(0.326)$ & $(0.313)$ & $(0.203)$ & $(0.198)$ & $(0.257)$ & $(0.240)$ \\
\hline \multirow[t]{2}{*}{$\mathrm{POP}^{\wedge} 2$} & $0.0515 * *$ & $0.0568^{* * *}$ & 0.0320 & 0.0241 & $-0.07 * * * *$ & $-0.07 * * *$ & $-0.06^{*}$ & $-0.06^{*}$ & 0.007 & 0.007 & 0.02 & 0.014 & -0.006 & -0.006 & -0.002 & -0.006 \\
\hline & $(0.021)$ & $(0.021)$ & $(0.03)$ & $(0.034)$ & $(0.025)$ & $(0.024)$ & $(0.03)$ & $(0.0350)$ & $(0.037)$ & $(0.039)$ & $(0.043)$ & $(0.0396)$ & $(0.0312)$ & $(0.0316)$ & $(0.0437)$ & $(0.0421)$ \\
\hline \multirow[t]{2}{*}{ DEBT Service } & 0.056 & 0.084 & 0.14 & 0.18 & -0.175 & -0.155 & $-0.30^{*}$ & $-0.29 *$ & -0.12 & -0.104 & -0.143 & -0.0784 & 0.219 & 0.225 & 0.224 & 0.171 \\
\hline & $(0.161)$ & $(0.131)$ & $(0.137)$ & $(0.147)$ & $(0.173)$ & $(0.159)$ & $(0.159)$ & $(0.169)$ & $(0.201)$ & $(0.185)$ & $(0.177)$ & $(0.165)$ & $(0.164)$ & $(0.158)$ & $(0.158)$ & $(0.191)$ \\
\hline Colon_british & & & & & & & & & $\begin{array}{l}1.57 * * * * \\
(0.302)\end{array}$ & $\begin{array}{l}1.60 * * * \\
(0.297)\end{array}$ & $\begin{array}{l}1.68^{* * * *} \\
(0.324)\end{array}$ & $\begin{array}{l}1.49 * * * \\
(0.342)\end{array}$ & & & & \\
\hline Colon_french & & & & & & & & & & & & & $\begin{array}{l}2.21 * * * * \\
(0.282)\end{array}$ & $\begin{array}{l}2.23 * * * \\
(0.29)\end{array}$ & $\begin{array}{l}2.062^{* * * *} \\
(0.347)\end{array}$ & $\begin{array}{l}1.800 \text { **** } \\
(0.410)\end{array}$ \\
\hline \multicolumn{17}{|c|}{ World Bank governance indicators } \\
\hline \multirow[t]{2}{*}{ CPIA } & & $0.831 * * *$ & 0.729 & 0.565 & & $0.538 *$ & 1.05 & 1.012 & & $0.532 *$ & 0.673 & 0.235 & & 0.0840 & 0.313 & 0.310 \\
\hline & & $(0.195)$ & $(0.499)$ & $(0.516)$ & & $(0.310)$ & $(0.668)$ & $(0.688)$ & & $(0.293)$ & $(0.686)$ & $(0.725)$ & & $(0.231)$ & $(0.560)$ & $(0.570)$ \\
\hline \multirow[t]{2}{*}{ WGI_Corruption } & & & $-0.61 *$ & -0.277 & & & $-0.99 * *$ & $-0.881 *$ & & & -0.49 & 0.053 & & & 0.350 & 0.119 \\
\hline & & & $(0.341)$ & $(0.36)$ & & & $(0.497)$ & $(0.491)$ & & & $(1.222)$ & $(1.220)$ & & & $(0.827)$ & $(0.844)$ \\
\hline \multirow[t]{2}{*}{ WGI_Government } & & & -0.107 & -0.288 & & & 0.674 & 0.612 & & & 0.563 & 0.560 & & & $-1.77 *$ & $-1.795^{*}$ \\
\hline & & & $(0.691)$ & $(0.696)$ & & & $(0.946)$ & $(0.950)$ & & & $(1.088)$ & $(0.987)$ & & & $(0.982)$ & $(0.970)$ \\
\hline \multirow[t]{2}{*}{ WGI_Stability } & & & 0.347 & 0.416 & & & $-0.49 * *$ & $-0.454 * *$ & & & 0.275 & 0.383 & & & 0.065 & 0.0542 \\
\hline & & & $(0.289)$ & $(0.275)$ & & & $(0.225)$ & $(0.223)$ & & & $(0.310)$ & $(0.282)$ & & & $(0.250)$ & $(0.260)$ \\
\hline \multirow[t]{2}{*}{ WGI_Law } & & & 0.887 & 0.720 & & & -0.078 & -0.166 & & & -0.805 & -1.239 & & & 0.264 & 0.422 \\
\hline & & & $(0.662)$ & $(0.639)$ & & & $(0.465)$ & $(0.474)$ & & & $(1.098)$ & $(1.050)$ & & & $(0.841)$ & $(0.840)$ \\
\hline \multirow[t]{2}{*}{ WGI_Regulatory } & & & -0.324 & -0.310 & & & -0.512 & -0.515 & & & 0.0733 & 0.102 & & & 0.575 & 0.784 \\
\hline & & & $(0.489)$ & $(0.502)$ & & & $(0.566)$ & $(0.572)$ & & & $(0.733)$ & $(0.728)$ & & & $(0.558)$ & $(0.573)$ \\
\hline \multirow[t]{2}{*}{ WGI_Voice } & & & -0.237 & -0.315 & & & 0.514 & 0.496 & & & -0.0272 & 0.0117 & & & 0.216 & 0.214 \\
\hline & & & $(0.248)$ & $(0.244)$ & & & $(0.319)$ & $(0.308)$ & & & $(0.377)$ & $(0.368)$ & & & $(0.271)$ & $(0.274)$ \\
\hline \multirow[t]{2}{*}{ DB rank } & & & & $-0.008^{* * *}$ & & & & -0.002 & & & & $-0.01 * *$ & & & & 0.006 \\
\hline & & & & $(0.003)$ & & & & $(0.005)$ & & & & $(0.004)$ & & & & $(0.005)$ \\
\hline Observations & 67 & 67 & 66 & 65 & 68 & 68 & 67 & 67 & 62 & 62 & 62 & 62 & 65 & 65 & 64 & 64 \\
\hline Adj R-squared & 0.610 & 0.671 & 0.696 & 0.699 & 0.590 & 0.605 & 0.617 & 0.612 & 0.696 & 0.710 & 0.698 & 0.718 & 0.584 & 0.577 & 0.558 & 0.562 \\
\hline
\end{tabular}




\begin{tabular}{|c|c|c|c|c|c|c|c|c|c|c|c|c|}
\hline & (34) & (35) & (36) & (37) & (38) & (39) & (40) & (41) & (42) & (43) & (44) & (45) \\
\hline VARIABLES & Netherlands & Netherlands & Netherlands & Netherlands & Denmark & Denmark & Denmark & Denmark & Germany & Germany & Germany & Germany \\
\hline \multicolumn{13}{|c|}{ Basic econometric model } \\
\hline \multirow[t]{2}{*}{ GNI pc } & $-5.888 *$ & -4.990 & $-5.730^{*}$ & $-5.917 *$ & $5.378^{*}$ & 5.241 & 2.475 & 2.999 & -0.874 & -0.351 & -1.705 & -1.705 \\
\hline & $(3.231)$ & $(3.091)$ & (3.134) & (3.059) & $(3.055)$ & (3.213) & (3.381) & (3.422) & (1.733) & (1.708) & (1.639) & $(1.684)$ \\
\hline \multirow[t]{2}{*}{ GNI pc^2 } & $0.501^{*}$ & 0.400 & $0.465^{*}$ & $0.466^{*}$ & -0.394 & -0.403 & -0.176 & -0.212 & 0.101 & 0.0447 & 0.165 & 0.163 \\
\hline & $(0.276)$ & $(0.266)$ & $(0.259)$ & $(0.251)$ & $(0.254)$ & $(0.271)$ & $(0.285)$ & $(0.287)$ & $(0.143)$ & $(0.142)$ & $(0.139)$ & $(0.141)$ \\
\hline \multirow[t]{2}{*}{ POP } & $1.043 * *$ & $1.040 * *$ & $1.721^{* * * *}$ & $1.630^{* * * *}$ & $0.785^{* * * *}$ & $0.646^{* * *}$ & $1.207 * * *$ & $1.163 * * *$ & $0.947^{* * * *}$ & $0.866^{* * * *}$ & $0.835 * * *$ & $0.832 * * * *$ \\
\hline & $(0.430)$ & $(0.394)$ & $(0.453)$ & $(0.507)$ & $(0.276)$ & $(0.312)$ & $(0.380)$ & $(0.383)$ & $(0.238)$ & $(0.228)$ & $(0.261)$ & $(0.266)$ \\
\hline \multirow[t]{2}{*}{$\mathrm{POP}^{\wedge} \mathbf{2}$} & -0.0414 & -0.0611 & -0.138 & -0.121 & -0.0251 & -0.0198 & -0.0859 & -0.0891 & -0.0368 & -0.0337 & -0.00865 & -0.00835 \\
\hline & $(0.0736)$ & $(0.0698)$ & $(0.0836)$ & $(0.0832)$ & $(0.0286)$ & $(0.0340)$ & $(0.0537)$ & $(0.0532)$ & $(0.0275)$ & $(0.0257)$ & $(0.0316)$ & $(0.0325)$ \\
\hline \multirow[t]{2}{*}{ DEBT Service } & -0.257 & -0.189 & -0.147 & -0.106 & $-0.364 *$ & -0.284 & -0.283 & -0.275 & 0.00699 & 0.0283 & -0.0693 & -0.0588 \\
\hline & $(0.276)$ & $(0.234)$ & $(0.222)$ & $(0.214)$ & $(0.189)$ & $(0.206)$ & $(0.245)$ & $(0.249)$ & $(0.184)$ & $(0.153)$ & $(0.159)$ & $(0.158)$ \\
\hline \multicolumn{13}{|c|}{ World Bank governance indicators } \\
\hline \multirow[t]{2}{*}{ CPIA } & & $1.052 * *$ & 0.175 & -0.123 & & $0.553^{*}$ & -0.0369 & 0.186 & & $0.531 * *$ & $1.155^{* * *}$ & $1.123 * *$ \\
\hline & & $(0.414)$ & $(0.810)$ & $(0.728)$ & & $(0.319)$ & $(0.836)$ & $(0.892)$ & & $(0.237)$ & $(0.535)$ & (0.533) \\
\hline \multirow[t]{2}{*}{ WGI_Corruption } & & & $2.020^{* * *}$ & $2.692 * * *$ & & & -0.437 & -0.916 & & & -0.836 & -0.744 \\
\hline & & & $(0.961)$ & $(0.968)$ & & & $(0.990)$ & $(1.014)$ & & & $(0.727)$ & $(0.731)$ \\
\hline \multirow[t]{2}{*}{ WGI_Government } & & & -0.480 & -0.857 & & & -0.317 & 0.0146 & & & -0.490 & -0.518 \\
\hline & & & $(1.185)$ & $(1.182)$ & & & $(1.254)$ & $(1.261)$ & & & $(0.667)$ & $(0.668)$ \\
\hline \multirow[t]{2}{*}{ WGI_Stability } & & & 0.307 & 0.487 & & & 0.394 & 0.278 & & & 0.275 & 0.297 \\
\hline & & & $(0.321)$ & $(0.326)$ & & & $(0.352)$ & $(0.367)$ & & & $(0.237)$ & $(0.236)$ \\
\hline \multirow[t]{2}{*}{ WGI_Law } & & & -0.463 & -0.991 & & & 1.004 & 1.315 & & & -0.0913 & -0.170 \\
\hline & & & (1.299) & $(1.263)$ & & & $(0.941)$ & $(0.959)$ & & & $(0.649)$ & $(0.632)$ \\
\hline \multirow[t]{2}{*}{ WGI_Regulatory } & & & -0.307 & -0.305 & & & -0.0745 & -0.128 & & & -0.168 & -0.162 \\
\hline & & & $(0.882)$ & $(0.843)$ & & & $(0.999)$ & $(0.984)$ & & & $(0.505)$ & $(0.502)$ \\
\hline \multirow[t]{2}{*}{ WGI_Voice } & & & $0.689 * *$ & $0.748 * *$ & & & 0.310 & 0.245 & & & 0.126 & 0.115 \\
\hline & & & $(0.328)$ & $(0.316)$ & & & $(0.534)$ & $(0.551)$ & & & $(0.194)$ & $(0.197)$ \\
\hline \multirow[t]{2}{*}{ DB rank } & & & & $-0.0109 *$ & & & & 0.00721 & & & & -0.00163 \\
\hline & & & & $(0.00546)$ & & & & $(0.00713)$ & & & & $(0.00349)$ \\
\hline Observations & 57 & 57 & 57 & 56 & 45 & 45 & 45 & 45 & 67 & 67 & 67 & 67 \\
\hline Adj R-squared & 0.190 & 0.280 & 0.359 & 0.355 & 0.212 & 0.234 & 0.226 & 0.227 & 0.706 & 0.725 & 0.742 & 0.738 \\
\hline
\end{tabular}

Notes: For each of the donor-based correlation models, the log of average ODA commitments over the period 2005- 08 are considered on the left hand side. In the basic model we account for: GNI per capita and the square of this variable, population and its square, and external debt service. For France and the UK a dummy variable is also introduced $(\star)$ reflecting the colonial status. $* * * \mathrm{p}<0.01, * * \mathrm{p}<0.05, * \mathrm{p}<0.1$. Aid data come from OECD/DAC online database while governance and the other variables are provided by the World Bank's WDI, 2009. 